\title{
Model Pembelajaran Nabi Muhammad SAW (Hiwar, Analogi , Tashbih, dan Amtsal)
}

\author{
Irjus Indrawan \\ Dosen Jurusan Manajemen Pendidikan Islam, Fakultas Ilmu Agama \\ Islam, Universitas Islam Indragiri (UNISI) Tembilahan
}

\begin{abstract}
Abstrak
Model pembelajaran adalah bentuk pembelajaran yang tergambar dari awal sampai akhir yang disajikan secara khas oleh guru. Adapun untuk menerapkan model tersebut dijabarkan kedalam bentuk metode pembelajaran yang merupakan prosedur, urutan, langkahlangkah, dan cara yang digunakan guru dalam pencapaian tujuan pembelajaran. Maka dapat dikatakan bahwa metode pembelajaran merupakan jabaran dari pendekatan, yang mana satu pendekatan dapat dijabarkan ke dalam berbagai metode pembelajaran. Nabi Muhammad SAW diutus oleh Allah SWT kepada umatnya untuk menanamkan ilmu sekaligus mensucikan jiwa. Mensucikan berarti membersihkan dari sifat buruk dengan pengajaran dan pendidikan serta memperhatikan situasi dan kondisi masyarakat. Nabi Muhammad apabila dikaitkan dalam dunia pendidikan, beliau adalah sosok pendidik yang sempurna dalam segala aspek. Beliau adalah pendidik yang telah memberikan contoh atau model pembelajaran yang sangat akurat, dengan memperhatikan situasi dan kondisi. Model pembelajaran Nabi Muhammad terhadap para sahabat adalah Hiwar, Analogi, Tashbih, dan Amtsal .
\end{abstract}

Key words: Model Pembelajaran, Nabi Muhammad sebagai Guru, Hiwar, Analogi, Tashbih, dan Amtsal

\section{A. Pendahuluan}

Model pada dasarnya berkaitan dengan rancangan yang dapat di gunakan untuk menerjemahkan sesuatu kedalam realitas, yang sifatnya lebih praktis. Adapun fungsinya sarana untuk mempermudah dan sebagai petunjuk bersifat perspektif dan petunjuk perencanaan untuk kegiatan pengelolaan. Selanjutnya untuk menerapkan model tersebut perlu di jabarkan kedalam bentuk metode pembelajaran, karena metode pembelajaran merupakan jabaran dari pendekatan. Apapun pendekatan dan model yang digunakan dalam mengajar, maka harus difasilitasi oleh metode mengajar. Menurut Nana Sudjana metode mengajar ialah cara yang digunakan guru dalam mengadakan hubungan dengan siswa pada saat berlangsungnya 
pengajaran. ${ }^{1}$

Para ilmuan muslim, terutama yang menaruh minat terhadap ilmu pendidikan Islam telah banyak menginterprestasikan dan menganalisis sistem nilai yang terkandung di dalam al-Qur'an dan alHadits yang mendasari proses kependidikan Islam. Dimana secara operasionalisasainya dalam bentuk tekhnisnya di wujudkan dalam berbagai ragam model serta metode. Karena sebuah model yang dituangkan kedalam metode pembelajaran akan mempengaruhi sampainya suatu informasi secara lengkap terhadap peserta didik.

Metode dalam mengajar berperan sebagai alat untuk menciptakan proses belajar mengajar dan belajar. Dengan metode diharapkan terjadinya interaksi belajar mengajar antara guru dan siswa dalam proses pembelajaran. Interaksi dalam proses belajar mengajar sering pula disebut dengan interaksi edukatif. Dalam interaksi edukatif baik siswa maupun guru menjalankan tugas dan perannya masing-masing. Guru sebagai salah satu sumber belajar, mengorganisir, memfasilitasi, serta memotivasi kegiatan belajar yang dilakukan oleh siswa. Sedangkan siswa melakukan aktifitas belajar dan memperoleh pengalaman belajar yang ditandai dengan adanya perubahan tingkah laku, baik kognitif, afektif, maupun psikomotor dengan bantuan dan bimbingan dari guru. ${ }^{2}$

Berkaitan dengan hal tersebut Rasulullah SAW sejak awal sudah mencontohkan dalam mengimplementasikan model pembelajaran yang tepat terhadap para sahabatnya. Yang mana strategi pembelajaran yang beliau lakukan sangat akurat dalam menyampaikan ajaran Islam. Rasulullah SAW sangat memperhatikan situasi, kondisi, dan karakter seseorang, sehingga nilai-nilai yang ada didalamnya dapat ditransfer dengan baik. Rasulullah SAW, juga sangat memahami naluri dan kondisi setiap orang, sehingga beliau mampu menjadikan mereka suka cita, baik material maupun spiritual. Dalam menyampaikan suatu pesan kepada peserta didik, jika antara topik pembahasan dengan metode yang digunakan dalam pembelajaran tidak singkron ataupun tidak sesuai maka tidak dapat dipungkiri

1 Nana Sudjana, Dasar-Dasar Proses Belajar Mengajar, (Bandung: Sinar Baru Algesindo. 2004), Hlm. 76.

2 Darwin Syah Dkk, Perencanaan Sistem Pengajaran Pendidikan Islam, (Jakarta: Gaung Persada Press; 2007), Hlm. 134. 
hasil yang akan dicapai tidak sempurna dengan kata lain apa yang dihasilkan tidak sesuai dengan harapan.

\section{B. Pembahasan}

\section{a. Pengertian Model Pembelajaran}

Dalam proses belajar mengajar, guru masih memegang peranan amat penting dan paling utama. Peranan guru masih belum bisa digantikan oleh alat elektronik yang canggih dan modern sekalipun. Masih banyak nilai-nilai manusiawi yang tidak dapat digantikan oleh alat elektronik seperti sikap, sistem nilai, perasaan, motivasi, kebiasaan, dan nilai-nilai lainnya seperti yang diharapkan dari tujuan pendidikan itu sendiri, karena pada dasarnya, tujuan dari pendidikan itu adalah untuk berkembangnya potensi peserta didik menjadi manusia berakhlak mulia, sehat, berilmu, cakap, kreatif, mandiri, demokrasi, dan bertanggung jawab. ${ }^{3}$ Sementara tujuan yang hendak dicapai adalah terbentuknya kepribadian yang bulat dan utuh sebagai manusia individual dan sosial serta hamba Tuhan yang mengabdi diri kepada-Nya.

Dalam proses belajar mengajar, agar tujuan utama dari pendidikan itu dapat tercapai, guru harus memiliki suatu cara ataupun model yang unik, menarik dan menyenangkan dalam menyampaikan pesan kepada peserta didik, dengan model yang unik, menarik, dan menyenangkan maka pesan yang diberikan kepada siswa akan mudah diterima dan dicerna oleh siswa. Model yang digunakan dalam proses pembelajaran sangat berpengaruh terhadap penguasaan siswa terhadap pesan yang diberikan, dengan kata lain, dalam proses pembelajaran jika model yang digunakan oleh guru tidak sesuai dengan kondisi maka hasil proses belajar mengajarpun tidak akan maksimal.

Model pembelajaran adalah bentuk pembelajaran yang tergambar dari awal sampai akhir yang disajikan secara khas oleh guru di kelas.Dalam model pembelajaran terdapat strategi pencapaian kompetensi siswa dengan pendekatan, metode, dan teknik pembelajaran.Pendekatan adalah konsep dasar yang mewadahi, menginspirasi, menguatkan, dan melatari metode pembelajaran dengan cakupan teoritis tertentu. Model pada dasarnya berkaitan dengan rancangan

3 Hasbullah, Dasar-Dasar Ilmu Pendidikan, (Jakarta: Raja Wali Press; 2005), hlm. 320. 
yang dapat di gunakan untuk menerjemahkan sesuatu kedalam realitas, yang sifatnya lebih praktis. Adapun fungsinya sarana untuk mempermudah dan sebagai petunjuk bersifat perspektif dan petunjuk perencanaan untuk kegiatan pengelolaan. ${ }^{4}$

Adapun untuk menerapkan model tersebut dijabarkan kedalam bentuk metode pembelajaran yang merupakan prosedur, urutan, langkah- langkah, dan cara yang digunakan guru dalam pencapaian tujuan pembelajaran. Maka dapat dikatakan bahwa metode pembelajaran merupakan jabaran dari pendekatan.Yang mana satu pendekatan dapat dijabarkan kedalam berbagai metode pembelajaran. Dalam pengertian lain, metode mengajar merupakan cara-cara yang digunakan guru untuk menyampaikan bahan pelajaran kepada siswa untuk mencapai tujuan. Dalam proses mengajar, makin tepat metode yang digunakan guru maka akan makin efektif proses belajar mengajar yang dilaksanakan yang selanjutnya akan menunjang dan mengantarkan keberhasilan belajar siswa dan keberhasilan mengajar yang dilakukan oleh guru. Tidaklah berlebihan jika ada sebuah ungkapan "aththariqah ahammu minal maddah", bahwa metode jauh lebih penting dibanding materi, karena sebaik apapun tujuan pendidikan, jika tidak didukung oleh metode yang tepat, tujuan tersebut sangat sulit untuk dapat tercapai dengan baik. Sebuah metode akan mempengaruhi sampai tidaknya suatu informasi secara lengkap atau tidak. $^{5}$

Salah satu komponen penting untuk mencapai keberhasilan pendidikan dalam mencapai tujuan adalah ketepatan menentukan metode, sebab tidak mungkin materi pendidikan dapat diterima dengan baik kecuali disampaikan dengan metode yang tepat. Metode diibaratkan sebagai alat yang dapat digunakan dalam suatu proses pencapaian tujuan, tanpa metode, suatu materi pelajaran tidak akan dapat berproses secara efisien dan efektif dalam kegiatan belajar mengajar menuju tujuan pendidikan.

Mengingat seluruh kegiatan pembelajaran yang dilakukan, baik

4 Wina Sanjaya, Kurikulum Dan Pembelajaran, Teori dan Praktik Pengembangan Kurikulum Tingkat Satuan Pendidikan (KTSP ),(Jakarta: Kencana Prenada media Group; 2008), hlm. 82.

5 Qomari Anwar, Pendidikan Sebagai Karakter Bangsa, (Jakarta: UHAMKA Press; 2003), hlm. 43. 
pembelajaran formal maupun pembelajaran informal, diarahkan untuk menggapai tujuan pendidikan. Abuddin Nata menyimpulkan bahwa tujuan pendidikan adalah membina manusia agar menjadi khalifah Allah di muka bumi. Akan tetapi, implementasi tujuan pendidikan tersebut harus disesuaikan dengan situasi dan kondisi suatu masyarakat, terutama peserta didik.Dengan demikian, implementasi tujuan pendidikan tersebut disesuaikan dengan bakat dan keahlian yang dimiliki oleh masing-masing peserta didik. ${ }^{6}$

Dengan demikian jelaslah bahwa agar tercapainya tujuan pendidikan sebagaimana yang diharapkan, diperlukan suatu strategi dan teknik yang sering dikenal dengan metode pembelajaran. Secara definitif, metode pembelajaran adalah suatu cara atau jalan yang ditempuh yang sesuai dan serasi untuk menyajikan suatu hal sehingga akan tercapai suatu tujuan pembelajaran yang efektif dan efisien sesuai dengan yang diharapkan.

Ada beragam metode pembelajaran yang sering digunakan oleh para pendidik dalam kegiatan belajar-mengajar.Di antaranya adalah metode ceramah, metode tanya-jawab, metode diskusi, metode sosio-drama (role playing), metode kerja kelompok, metode pemecahan masalah (problem solving), metode karyawisata (field-trip), metode survai masyarakat, dan sebagainya. ${ }^{7}$ Sekalipun dibahas secara berpisah untuk masing-masing metode mengajar bukan berarti dalam praktek masingg-masing metode tersebut berdiri sendiri-sendiri. Proses belajar mengajar yang baik adalah mempergunakan berbagai jenis metode mengajar secara bergantian atau saling bahu membahu satu dengan yang lainnya, karena masing-masing metode memiliki kekurangan dan kelebihan. Tugas guru adalah memilih berbagai metode yang tepat untuk menciptakan proses belajar mengajar.

\section{b. Kesempurnaan Nabi Muhammad SAW Sebagai Guru}

Keberadaan Nabi Muhammad SAW sebagai seorang guru sekaligus materi pendidikannya yang merupakan tugas kerasulannya sudah dirancang dan di persiapkan Allah SWT. Sebagaimana firman Allah dalam Q.S Al Jumu'ah : 2

Dia-lah yang mengutus kepada kaum yang buta huruf seorang Rasul

6 Ibrahim, Inovasi Pendidikan, (Jakarta; Grasindo;1998), hlm. 89.

7 Gulo, Strategi Belajar Mengajar, (Jakarta: Grasindo; 2002), hlm. 78. 
di antara mereka, yang membacakan ayat-ayat-Nya kepada mereka, mensucikan mereka dan mengajarkan mereka Kitab dan hikmah (As Sunnah). dan Sesungguhnya mereka sebelumnya benar-benar dalam kesesatan yang nyata

Senada dengan ayat diatas adalah firman Allah SWT dalam Q.S Ali Imran ayat 164 :

Sungguh Allah Telah memberi karunia kepada orang-orang yang beriman ketika Allah mengutus diantara mereka seorang Rasul dari golongan mereka sendiri, yang membacakan kepada mereka ayat-ayat Allah, membersihkan (jiwa) mereka, dan mengajarkan kepada mereka Al Kitab dan Al hikmah. dan Sesungguhnya sebelum (kedatangan Nabi) itu, mereka adalah benar-benar dalam kesesatan yang nyata.

Kedua ayat diatas menjelaskan bahwa nabi Muhammad SAW diutus oleh Allah swt kepada umatnya untuk menanamkan ilmu sekaligus mensucikan jiwa mereka. Mensucikan berarti membersihkan dari sifat buruk yang merupakan sebagian besar masyarakat Makkah pada masa itu, dengan pengajaran dan pendidikan dengan memperhatikan situasi dan kondisi masyarakat pada waktu itu. ${ }^{8}$ Dan kedudukan beliau sebagai seorang pendidik ( guru ) dinyatakan dalam sabdanya : "Sesungguhnya Allah yang mengutusku sebagai seorang mu'allim dan pemberi kemudahan”. Dan Rasulullah saw telah bersungguh-sungguh dalam mendidik para sahabat dan generasi muslim, hingga mereka memiliki kesempurnaan akhlak, kesucian jiwa dan karakter yang bersih. ${ }^{9}$

Sebagaimana Rasulullah saw selalu memerintahkan kebaikan kepada manusia dan beliau adalah orang pertama yang melakukannya dan beliau mencegah manusia dari kejahatan, maka beliau adalah orang pertama yang menjauhinya. Ini adalah kesempurnaan akhlak beliau. Tidaklah mengherankan, karena akhlak beliau adalah al Qur'an. ${ }^{10}$

8 Alfiah, Hadis Tarbawiy ( Pendidikan Islam Tinjauan Hadis Nabi ), (Pekanbaru: Al Mujtahadah Press; 2010), hlm.83.

9 Ibid., hal : 83

10 Fu'ad Asy Syalhub, Guruku Muhammad SAW, (Jakarta: Gema Insani; 2006), hlm. 11. 
Maka berkaitan dengan penjelasan tersebut, nabi Muhammad saw adalah sebagai uswatun hasanah, dan tentunya termasuk sebagai sosok guru yang telah nyata dan jelas serta melebihi atas semua sifat dan syarat seorang guru yang telah ditetapkan oleh para ahli pendidikan. An Nahlawi Misalnya, menetapkan sepuluh sifat dan syarat bagi seorang guru, yaitu: memiliki sifat rabbani, menyempurnakan sifat rabbani dengan keikhlasan, mengajarkan ilmu dengan sabar, memiliki kejujuran, berpengetahuan luas di bidangnya, cerdik dan trampil menciptakan metode dalam pengajaran,tegas dan proporsional, memahami karakter dan kemampuan anak didik, peka terhadap fenomena kehidupan dan bersikap adil. ${ }^{11}$

Dengan demikian penulis berpendapat bahwa nabi Muhammad SAW sebagai "uswatun hasanah". Dan apabila dikaitkan dalam dunia pendidikan, beliau adalah sosok pendidik yang sempurna dalam segala aspek. Beliau adalah pendidik yang telah memberikan contoh atau model pembelajaran yang sangat akurat, dengan memperhatikan situasi dan kondisi. Dan adapun model yang telah beliau terapkan tersebut terbukti dalam dalam mendidik para sahabat dan umat manusia pada umumnya sehingga meraih keberhasilan untuk mencapai tujuan pendidikan.

Merujuk pada pola kependidikan dan keguruan Rasuluullah SAW, dalam perspektif Islam, guru menjadi posisi kunci dalam membentuk kepribadian muslim yang sejati. Keberhasilan Rasulullah dalam mengajar dan mendidik umatnya lebih menyentuh prilaku, yaitu contoh teladan yang baik (uswatun hasanah). Hal ini bukan berarti aspek-aspek selain dari prilaku di abaikan. Aspek prilaku dalam proses pengajaran posisinya sangat penting. Sebagai seorang guru, apalagi seorang guru agama Islam harus bisa menjadi contoh, panutan, idola, dan teladan yang baik (uswatun hasanah) bagi para siswanya. Segala prilaku guru dalam proses pembelajaran bahkan diluar proses pembelajaran, prilaku guru akan ditiru oleh para siswa. Oleh karena itu guru harus menjaga prilakunya secara baik dan menjadi suri tauladan (uswatun hasanah) bagi para siswanya.

Adapun kajian tentang keberhasilan pendidikan dan pengajaran yang dilakukan oleh nabi Muhammad SAW tersebut, tidak saja dilakukan oleh umat Islam, tetapi hal diatas juga telah diungkapkan

11 Alfiah, Op. cit., hlm. 85 
oleh selain Islam, diantaranya oleh James E. Royster, bahwa Nabi Muhammad SAW Tidak hanya menjadi guru bagi generasi masanya saja, tetapi juga pada masa sekarang dan menjadi seorang imaginary educator. ${ }^{12}$

\section{c. Model-model Pembelajaran Nabi Terhadap Sahabat}

Sebenarnya, urgensi penggunaan model pembelajaran dalam dunia pendidikan telah dicontohkan oleh Nabi Muhammad saw. Salah satunya adalah hadis berikut ini:

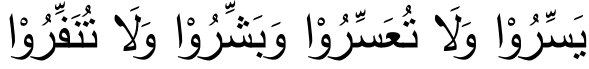

Mudahkanlah dan janganlah kamu mempersulit. Gembirakanlah dan janganlah kamu membuat mereka lari. ( H.R Bukhari).

Dalam hadis di atas, secara tersirat Rasulullah saw memerintahkan kepada kita untuk menyelenggarakan suatu kegiatan pembelajaran yang menyenangkan dan tidak sulit. Inilah sebenarnya salah satu metode yang cukup ideal dan bisa memberikan hasil yang optimal.

Selain Hadis di atas, masih banyak Hadis lain yang mengisyaratkan metode pembelajaran ala $\mathrm{Nabi}$, atau dengan kata lain prophetic learning, pembelajaran berbasis kenabian. Di antaranya adalah metode keteladanan dan akhlak mulia, metode pembelajaran secara bertahap, metode pembelajaran dengan memperhatikan situasi dan kondisi peserta didik, metode tamsil, metode isyarat, dan metode tanya-jawab.

Dengan berdasarkan beberapa ayat al-Qur'an, Hadis, dan penjelasan tersebut di atas, penulis menyimpulkan bahwa ajaran Islam mengandung sumber inspirasi yang tidak akan pernah kering untuk mengembangkan ilmu pengetahuan, khususnya untuk mengembangkan model pembelajaran. Hal ini terbukti dengan begitu beragamnya ungkapan Hadis Nabi yang berkaitan langsung dengannya dalam mendidik para sahabat. Model pembelajaran yang dilakukan nabi Muhammad saw terhadap para sahabat adalah sebagai berikut:

12 Ibid., hal. 90. 


\section{1) Model Hiwar}

Adapun hiwar diartikan sebagai dialog antara dua pihak atau lebih yang di lakukan melalui tanya jawab dan didalamnya terdapat kesatuan topik atau tujuan dialog. ${ }^{13}$ Yang dimaksud hiwar adalah percakapan silih berganti antara dua pihak atau lebih melalui tanya jawab mengenai suatu topik yang mengarah pada suatu tujuan. Percakapan ini bisa dialog langsung dan melibatkan kedua belah pihak secara aktif, atau bisa juga yang aktif hanya salah satu pihak saja, sedang pihak lain hanya merespon dengan segenap perasaan, penghayatan dan kepribadiannya.

Model Hiwar adalah metode mengajar yang memungkinkan terjadinya komunikasi langsung yang bersifat two way traffic, sebab pada saat yang sama terjadi dialog antara guru dan siswa. Guru bertanya sedangkan siswa menjawab atau siswa bertanya dan guru menjawab. Dalam komunikasi ini terlihat adanya hubungan timbal balik secara langsung antara guru dengan siswa.Dalam hiwar ini kadangkadang keduanya sampai pada suatu kesimpulan, atau mungkin salah satu pihak tidak merasa puas dengan pembicaraan lawan bicaranya. Namun demikian ia masih dapat mengambil pelajaran dan menentukan sikap bagi dirinya. ${ }^{14}$

Mani bin Abd al-Aziz al-Mani menyebutkan, bahwa hiwar disebut juga dengan metode tanya jawab. Hal ini senada dengan apa yang dikatakan oleh H.M. Arifin dalam bukunya "Ilmu Pendidikan Islam". 15

Salah satu yang menonjol dari model Nabi SAW dalam mengajar adalah kerap kali beliau mengajar para sahabat dengan cara berdialog ( Hiwar) dan tanya jawab. Sebab dialog sangat membantu sekali dalam membuka kebuntuan otak dan kebekuan berpikir. ${ }^{16}$

Contoh dari itu, suatu hari Nabi bertanya pada sahabatsahabatnya, "Andai di depan rumah kalian ada sungai, lalu kalian

\section{Alfiah, Op. Cit.}

14 Abdurrahman an-Nahlawi, Prinsip-prinsip Dasar Metode Pendidikan Islam dalam Keluarga di Sekolah dan di Masyarakat, Terj. Herry Noer Ali (Bandung: Diponegoro, 1989)

15 Arifin, Ilmu Pendidikan Islam, (Jakarta: Bumi Aksara; 1996), hlm.215.

16 Abdurrahman an-Nahlawi, Op. Cit., hlm. 284. 
mandi 5 kali sehari, apakah akan ada kotoran yang tertinggal di tubuh (kalian)?" "Tentu tidak wahai Rasul," jawab mereka. Begitu juga shalat 5 waktu, yang dengannya dosa-dosa dan segala kesalahan dihapus oleh Allah Ta'ala.” (HR. Bukhari dan Muslim) ${ }^{17}$

Atau pertanyaan beliau, "Kalian tahu tidak, siapakah muslim itu?" "Allah dan Rasul yang lebih tahu," jawab para sahabat. "Orang muslim adalah orang yang teman-teman dia selamat dari gangguan lidah dan tangannya. Kalau orang Mu'min?" "Allah dan Rasul yang lebih tahu." "Adalah orang yang teman-temannya merasa aman atas diri dan harta mereka dari gangguannya. Sedangkan Muhajir adalah orang yang meninggalkan kejelekan-kejelekan dan menghindarinya (HR. Ahmad)

"Kalau orang yang bangkrut itu bagaimana?" tanya beliau juga pada para sahabat di lain kesempatan. "Tentu saja orang yang tidak punya uang dan harta," jawab para sahabat beliau. Dengan bijak beliau menjawab, "Sesungguhnya orang yang bangkrut di kalangan ummatku adalah orang yang datang pada hari kiamat dengan amal ibadah tidak lengkap. Hanya sayangnya dia suka mencaci maki, menggunjing, korupsi, mengganggu, sehingga semua pahala amal baiknya digunakan untuk menebus keburukan-keburukan itu sampai habis. Jika keburukannya itu belum tertebus semua, maka kesalahankesalahan orang lain yang disakitinya ditimpakan kepadanya. Dan pada akhirnya dia diceburkan ke neraka." (HR. Muslim)

Adapun selanjutnya contoh metode dialog yang sangat terkenal adalah hadits Jibril, dalam pelajaran penting tentang dasardasar teologi, yang disampaikan di hadapan para sahabatnya dalam bentuk dialog antara beliau saw dengan malaikat Jibril (yang datang menyamar dalam bentuk manusia). Umar ra. bertutur, "Ketika kita sedang duduk-duduk dengan Rasul, tiba-tiba datang seseorang dengan pakaian putih bersih, penampilannya sangat rapi, tak satupun dari kami yang mengenalnya. Dan dia segera mengambil posisi dengan duduk sopan berhadapan langsung dengan Nabi saw. Lalu dia membuka percakapan. "Ya Muhammad, beri tahu aku tentang Islam!" "Islam itu, kamu bersaksi tiada Tuhan selain Allah dan Muhammad adalah utusan-Nya, lalu kamu mendirikan shalat, menunaikan zakat, berpuasa pada bulan Ramadan, dan haji jika kamu

17 Shahih Muslim, Jilid I, hal: 463. 
mampu," jawab Rasul saw. "Ya, jawabanmu benar," kata orang tadi. Tentu saja kami heran, ini orang datang bertanya, dijawab, tapi juga membenarkan jawaban itu.

"Sekarang beri tahu aku tentang Iman!" tanya orang itu lagi. "Iman adalah kamu percaya pada Allah, malaikat-malaikat-Nya, kitab-kitab suci-Nya, para rasul utusan-Nya, hari akhir (kiamat), dan kamu percaya akan takdir, baik dan buruknya," jawab Rasul saw. "Benar apa yang kamu katakan itu," komentar orang itu lagi.

"Beri tahu aku juga tentang Ihsan!"t anya orang itu lagi. "Ihsan, kamu menyembah Allah, seolah-olah kamu melihat-Nya, meskipun kamu tidak melihat-Nya, tapi Dia melihatmu." "Dan kapan hari kiamat?" "Kalau ini, kita sama-sama tidak tahu," jawab Rasul diplomatis. "Jika begitu, beri tahu aku tanda-tandanya!" "(Di antara) tandanya, jika seorang budak melahirkan tuannya, dan jika kamu melihat orang-orang pedesaan (yang rata-rata miskin itu) saling berlomba membangun bangunan yang tinggi." Setelah itu orang tadi pun pergi, Nabi saw bertanya kepadaku, "Umar, kamu tahu tidak, siapa orang yang bertanya padaku itu?" "Allah dan Rasul lebih tahu," jawabku. "Dia adalah Jibril. Dia datang kepada kalian untuk mengajarkan pada kalian tentang (inti agama yang kalian peluk."” (H.R. Muslim) $)^{18}$

\section{2) Analogi (kias)}

Sesekali dalam mengajar, Rasulullah SAW menggunakan analogi (perbandingan secara kias dengan bentuk yang sudah ada) terhadap suatu hukum atau ajaran yang kurang bisa dipahami dengan baik oleh sebagian sahabatnya, juga menjelaskan sebab-sebab akan sebuah hukum. ${ }^{19}$

Dengan penyepadanan dan analogi itu, para sahabatnya pun kemudian paham terhadap suatu hukum dan tujuan diterapkannya syari'at itu (maqasid at-Tasyri'). Seperti yang beliau contohkan saat seorang perempuan dari suku Juhainah bertanya pada beliau, "Sesungguhnya ibuku telah bernadzar untuk haji, tetapi sampai beliau

18 Al Imam An -Nawawi, Empat Puluh hadits Sahih, (Saudi Arabia: Direktorat Percetakan Dan Penerbitan Agama; 1422 H), hlm. 20.

19 Wina Sanjaya, Pengembangan model pembelajaran metode klinis bagi peningkatan kemampuan belajar siswa,( Jakarta: Bulan Bintang;2002), hlm. 77 
meninggal belum sempat berhaji melaksanakan nadzarnya itu. Apakah saya bisa berhaji (menggantikannya) atas nama beliau?" "Ya, bisa. Bukankah jika ibumu punya hutang dan belum sempat dilunasinya, lalu dia meninggal, kamu juga kan yang melunasi hutangnya?” jawab Rasul."Ya, memang begitu," kata wanita itu lega. (H.R. Bukhari)

\section{3) Tashbih dan Amtsal}

Shabah (tashbih) secara harfiah semakna dengan amtsal (matsal) berarti serupa, sama, atau seperti. Dalam bahasa Arab kata ini di gunakan untuk menyamakan sesuatu yang lain, seperti tergambar dalam ungkapan "anta mitslu asy syamsi" (anda bagaikan matahari). ${ }^{20}$

Dalam banyak kesempatan saat mengajar, Rasul SAW juga menggunakan tashbih dan amtsal untuk menjelaskan suatu makna dari ajaran yang beliau sampaikan. Dalam penjelasannya, beliau menggunakan media benda yang banyak dilihat orang, atau yang mereka rasakan, atau yang mereka pegang. Hal ini sangat memudahkan pelajar untuk mendeskripsikan suatu masalah yang mungkin kurang jelas baginya. Cara ini umum digunakan oleh pengajarpengajar sastra,dan telah disepakati oleh mereka bahwa penggunaan tashbih dan amtsal memiliki pengaruh besar dan sangat membantu dalam menjelaskan sebuah arti yang samar dan kurang jelas. Dalam Al-Qur'an banyak sekali ayat yang menggunakan perumpamaan, dan tentu saja Nabi SAW banyak mengikuti metode al-Qur'an ini dalam forum-forum pidato, orasi, dan cara mengajar beliau. ${ }^{21}$

Contoh sabda beliau SAW berkenaan dengan tasbih dan amtsal ini sebagaimana disebutkan dalam shahih Muslim. Hadis dari Abu Musa Al Asy'ari radhiyallahu 'anhu, "Perumpamaan orang mukmin yang membaca al-Qur'an itu laksana utrujah, rasanya lezat dan aromanya wangi. Sedangkan mukmin yang tidak membaca al-Qur'an itu seperti kurma, rasanya enak tetapi tidak ada aromanya. Adapun orang munafik yang membaca al-Qur'an, itu seperti raihanah, aromanya harum, tapi rasanya pahit. Sedang orang munafik yang tidak baca al-Qur'an, itu seperti hanzalah, pahit rasanya juga tidak

20 Kadar M. Yusuf, Tafsir Tarbawi, (Yogyakarta:Zanafa;2001), hlm. 122.

21 WinaSanjaya. Pengembangan Kurikulum dan Pembelajaran, (Jakarta: KencanaPerdana Media Group: 2005), hlm. 35. 
ada aromanya." (HR. Bukhari dan Muslim). ${ }^{22}$ Atau sabda beliau yang lain, "Perumpamaan teman yang baik itu seperti pedagang minyak wangi, jika kamu tidak diberinya sedikit, maka kamu mendapat harum wanginya. Sedangkan teman yang buruk, itu seperti pandai besi, jika kamu tidak terkena percikan kecil apinya, maka kamu terkena asapnya."

Dengan demikian perumpamaan seperti ini, terkadang suatu permasalahan tampak lebih jelas dan lebih menancap kuat dalam hati dan ingatan para peserta didik dalam proses belajar mengajar.

\section{Kesimpulan}

Model pada dasarnya berkaitan dengan rancangan yang dapat di gunakan untuk menerjemahkan sesuatu kedalam realitas, yang sifatnya lebih praktis. Adapun fungsinya sarana untuk mempermudah dan sebagai petunjuk bersifat perspektif dan petunjuk perencanaan untuk kegiatan pengelolaan. Model pembelajaran adalah bentuk pembelajaran yang tergambar dari awal sampai akhir yang disajikan secara khas oleh guru di kelas.Dalam model pembelajaran terdapat strategi pencapaian kompetensi siswa dengan pendekatan, metode, dan teknik pembelajaran.

Nabi Muhammad saw adalah sebagai uswatun hasanah, apabila dikaitkan dalam dunia pendidikan, beliau adalah sosok pendidik yang sempurna dalam segala aspek dan tentunya melebihi atas semua sifat dan syarat seorang guru yang telah ditetapkan oleh para ahli pendidikan. Dan beliau adalah seorang pendidik yang telah memberikan contoh atau model pembelajaran yang sangat akurat, dengan memperhatikan situasi dan kondisi. Dan adapun model yang telah beliau terapkan telah terbukti dalam mendidik para sahabat dan umat manusia pada umumnya sehingga meraih keberhasilan untuk mencapai tujuan pendidikan.

Dengan demikian model pembelajaran dalam pendidikan yang dicontohkan oleh Rasulullah saw seperti: hiwar dan tanya jawab, analogy (kias), tashbih dan amtsal, merupakan model yang efektif. Guru dituntut untuk mampu mewujudkan perilaku mengajar secara tepat agar terjadinya prilaku belajar yang efektif pula dalam

22 Ibnu Qayyim Al-Jauziyah, Buah Ilmu, Penerjemah Fadhli Bahri, Pustaka Azzam, Jakarta, 1999, hal : 23. 
diri siswa. Guru diharapkan mampu menciptakan interaksi belajar mengajar yang sedemikian rupa sehingga siswa mewujudkan kualitas prilaku belajarnya secara efektif. Guru juga dituntut untuk mampu menciptakan situasi yang kondusif, karena situasi yang kondusif dalam proses belajar mengajar dapat dijadikan indikasi keberhasilan mengajar, karena situasi yang kondusif proses belajar mengajar akan bisa terwujud.

\section{Daftar Pustaka}

Abdurrahman an-Nahlawi, Prinsip-prinsip Dasar Metode Pendidikan Islam dalam Keluarga di Sekolah dan di Masyarakat, Terj. Herry Noer Ali Bandung: Diponegoro, 1989

Arifin, Ilmu Pendidikan Islam, Jakarta: Bumi Aksara; 1996

Al Imam An -Nawawi, Empat Puluh hadits Sahih, Saudi Arabia: Direktorat Percetakan Dan Penerbitan Agama;1422 H

Alfiah, Hadis Tarbawiy ( Pendidikan Islam Tinjauan Hadis Nabi ),Pekanbaru:Al Mujtahadah Press;2010

Darwin Syah Dkk., Perencanaan Sistem Pengajaran Pendidikan Islam, Jakarta: Gaung Persada Press. 2007

Fu'ad Asy Syalhub, Guruku Muhammad SAW, Jakarta: Gema Insani; 2006

Gulo, Strategi Belajar Mengajar, , Jakarta: Grasindo; 2002

Hasbullah, Dasar-Dasar Ilmu Pendidikan, Jakart: Raja Wali Press; 2005

Ibnu Qayyim Al-Jauziyah, Buah Ilmu, Penerjemah Fadhli Bahri, Jakarta: Pustaka Azzam, 1999

Ibrahim, Inovasi Pendidikan, Jakarta: Grasindo;1998

Kadar M. Yusuf, Tafsir Tarbawi,Yogyakarta: Zanafa; 2001

Nana Sudjana, Dasar-Dasar Proses Belajar Mengajar, Bandung: Sinar Baru Algesindo; 2004

Qomari Anwar, Pendidikan Sebagai Karakter Bangsa, Jakarta: UHAMKA Press; 2003

Shahih Muslim, Jilid I

Wina Sanjaya, Kurikulum Dan Pembelajaran, Teori dan Praktik Pengembangan Kurikulum Tingkat Satuan Pendidikan (KTSP), Jakarta: Kencana Prenada media Group: 2008. 
$74 \frac{\text { Jurnal AL-AFKAR }}{\text { Vol. II, No. II, Oktober } 2013}$

. Pengembangan model pembelajaran metode klinis bagi peningkatan kemampuan belajar siswa, Jakarta: Bulan Bintang; 2002

- Pengembangan Kurikulum dan Pembelajaran, Jakarta: kencanaPerdana media group; 2005 


\title{
Aplikasi Teknologi Di Dalam Proses Pengajaran Dan Pembelajaran Subjek Pengajian Islam Berasaskan Masalah (PBL): Suatu Perkongsian, Analisa Dan Aspek Cabaran Semasa Di Universiti Tun Hussein Onn Malaysia
}

\author{
Dr. Rafiuddin Afkari, dkk.
}

\section{A. Pengenalan}

Di Universiti Tun Hussein Onn Malaysia, subjek Pengajian Islam merupakan antara matapelajaran wajib universiti yang dikendalikan oleh pensyarah di bawah Panel Bidang Pengajian Islam, Jabatan Pengajian Islam dan Sains Sosial. Di awal penawaran matapelajaran tersebut tahun 2001 untuk Subjek Pengajian Islam, pendekatan syarahan digunakan bagi menyampaikan kandungan matapelajaran.

Pengajaran dan Pembelajaran Subjek Pengajian Islam di UTHM adalah bidang ilmu yang amat penting pada masa kini di mana sahaja, sama ada kepada pelajar khasnya dan umat Islam sendiri mahu pun kepada non-muslim. Hal ini disebabkan beberapa faktor. Antara yang patut dinyatakan adalah; i) antara masalah utama umat Islam pada masa kini di seluruh dunia adalah masalah kelemahan dalam bidang kurangnya pemahaman, penghayatan dan pengamalan ilmu Pengajian Islam yang bersumberkan pada al-Quran dan alSunnah; ii) masalah antara umat Islam dengan dunia Barat antara lain disebabkan salah faham dan persepsi terhadap umat Islam sehingga munculnya pelbagai idea termasuk Islam Fobia yang justeru akan menepis pandangan negatif Barat dan non-muslim terhadap Islam; iii) Pemahaman, penghayatan dan pengamalan terhadap Pengajian Islam di UTHM harus diperhebahkan dan diperhebatkan lagi berbagai konsep, teori dan aplikasinya sehingga melahirkan mahasiswa yang unggul dan matang dari segi pemikiran dan akidah.

Bermula tahun 2006 pendekatan Pembelajaran Berasaskan Masalah (PBM) atau Problem Based Learning (PBL) telah digunak- 
an bagi melaksanakan pembelajaran berpusatkan kepada pelajar (Student Centerd Learning). Pada peringkat awal ia dilaksanakan tanpa berpandukan kepada modul yang khusus kerana jumlah pelajar yang ramai bagi satu masa dan kemudahan dewan kuliah yang terhad menyukarkan pensyarah melaksanakan modul PBL yang diperkenal dalam sesi latihan yang dijalankan oleh Pusat Pengajaran dan Pembelajaran Universiti.

Pada tahun 2009 sebuah modul PBL telah disusun dengan mengambilkira kekangan yang ada dan ia digunakan oleh hampir semua pensyarah yang mengajar Pengajian Islam. Hasil dari pelaksanaan modul tersebut didapati pendekatan PBL ini telah membuka ruang kepada pelajar mengaplikasi dan menggunakan teknologi dalam melaksanakan tugasan yang diberi.

Sehubungan itu, Subjek Pengajian Islam memainkan peranan yang amat penting dalam membina kefahaman Islam yang betul, benar dan baik, sama ada di kalangan pelajar UTHM khasnya dan umat Islam atau orang bukan Islam pada amnya. Pengajian ini, selain dapat berfungsi sebagai pendefinisi atau pentakrif kepada umat Islam, ia juga dapat mengelakkan salah faham dan tidak kefahaman non-muslim yang boleh membawa kepada pertembungan agama dan peradaban. Berasaskan kesedaran ini, kertas kerja ini cuba untuk melihat realiti Pengajian Islam di UTHM. Ia juga akan menganalisis cabaran, isu semasa dan mengemukakan prospek Pengajian Islam di Malaysia.

\section{B. Pembahasan}

a. Konsep Pengajian Islam

Pengajian Islam adalah bukan suatu bidang ilmu baru. Istilah "Pengajian Islam" itu sendiri adalah bukan istilah yang baru. Hal ini amat jelas apabila tidak dapat ditemui sebuahpun karya turath Islam yang bertajuk "al-Aqidah al-Islamiyyah wa usuluha" atau mengandungi istilah tersebut dalam tajuknya. Sehubungan itu, Pengajian Islam memerlukan konsepsi yang jelas sebelum boleh dijadikan suatu bidang pengajian.

Dalam hal ini Al-Maydani, 'Abd. Al-Rahman Hasan Habannakah mendefinisikan pengajian Islam sebagai asas utama peraturanan dan panduan hidup (ad-deen) oleh para ulama Muslim untuk meng- 
huraikan Islam berdasarkan sumbernya yang asli iaitu al-Qur'an dan al-Sunnah. Al-Buti, Muhammad Sa'id Ramadan mendefinisikannya sebagai suatu cara hidup dimana agama adalah suatu sistem yang mengandungi peraturan yang menyeluruh, undang-undang yang lengkap dalam semua urusan hidup manusia untuk mereka menerima dan mengamalkannya secara total dengan cara :

1. Mentaati dan mematuhi segala perintahNya (suruhan dan larangan)

2. Memahami bahawa peraturan yang ditentukan oleh Islam bersesuaian dengan fitrah manusia

3. Menerima dan mengamalkan secara total segala perintah dan peraturan Islam dalam kehidupan

4. Menjadikan Islam sebagai undang-undang dan peraturan yang lengkap dalam semua urusan kehidupan

Kesempurnaan seseorang muslim bergantung kepada sejauhmana kepatuhannya kepada perintah dan peraturan yang ditetapkan oleh Islam. Sebagaimana firman Allah dalam surah al-Baqarah, ayat 208 :

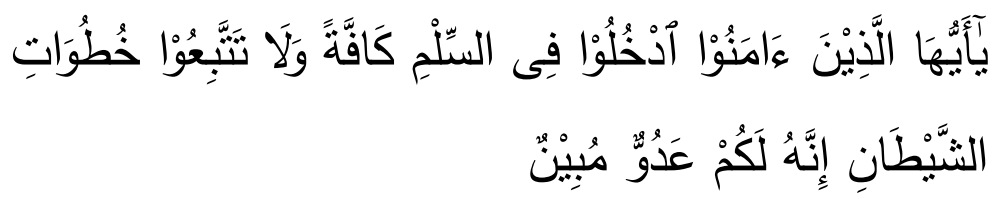

"Wahai orang-orang beriman, masuklah kamu ke dalam agama Islam (dengan mematuhi) seluruh hukum-hukumnya. Jangan kamu mengikuti langkah-langkah syaitan. Sesungguhnya syaitan itu musuh yang nyata bagimu."

Terdapat banyak ayat dalam al-Quran yang menyebut Islam sebagai ad-Deen. Antaranya: firman Allah dalam surah al-Maidah, ayat 3:

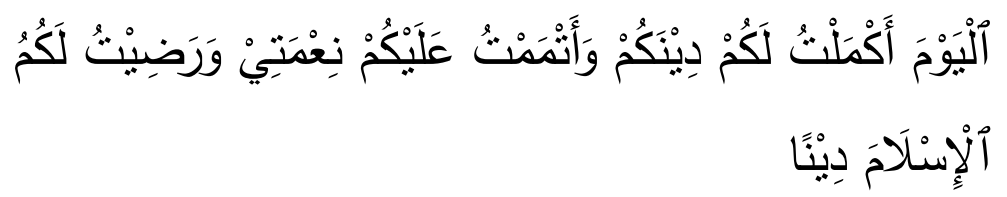

"Hari ini Aku telah sempurnakan agama kamu dan telah sempurnakan kepadamu nikmatKu dan Aku telah redha Islam itu menjadi agama untuk kamu." 
Setiap apa yang dilahirkan oleh pemikiran kaum Muslim sejak perutusan Rasulullah hingga kini tentang pandangan hidup umum (al-ma'arif kawniyyah, world view) yang berhubungan dengan Allah SWT, alam dan manusia. Dengan itu, dapat dirumuskan bahawa konsep pengajian Islam meliputi beberapa aspek, iaitu; i) Islam sebagai ad-deen bersumberkan nas wahyu iaitu al-Qur'an dan al-Sunnah; ii) Sumber rujukan dalam Islam; iii) Pengajian Ulum Al-Quran dan Ulum Al-Hadith; iv) Aqidah Ahli Sunnah wal-Jamaah; v) Aliran pemikiran aqidah dan perbahasannya; vi) Perkembangan mazhab fiqh dan perbahasannya; vii) Prinsip muamalat Islam; viii) Maqasid Syariah dan undang-undang jenayah Islam; ix) Etika kerja Islam; dan x) Undang-undang kekeluargaan Islam.

Seterusnya, perlu difahami bahawa pengajian Islam bukan sekadar pengajaran-pembelajaran namun sangat menekankan aspek penghayatan ilmu yang disampaikannya secara mendalam. Dengan itu, Pengajian Islam bukan sekadar syarahan semata-mata daripada pensyarah kepada pelajar atau mahasiswanya dalam bentuk sehala. Malah pengajian melibatkan gerak kerja aktif pelajar menyelidiki dan meneliti serta perlunya penghayatan lebih mendalam daripada pelbagai sumber tentang topik perbahasan ilmu Pengajian Islam.

Daripada kefahaman tersebut, maka pengajian melibatkan sekurang-kurangnya empat elemen utama, iaitu; i) Ilmu yang diajar iaitu topik-topik dalam skop pengajian Islam, ii) Metodologi pengajian, sama ada kuliah syarahan, perbincangan tutorial, tugasan penyelidikan dan penulisan laporan, pembentangan hasil kajian, kuis, menduduki peperiksaan/ujian dan sebagainya, serta termasuk dalam hal ini adalah sumber-sumber ilmu pengajian Islam, khususnya buku, para ilmuwan Islam yang masih hidup, seminar-seminar berkaitan dengan Pengajian Islam semasa dalam pelbagai saluran, iii) Pelajar, dan iv) Pengajar.

b. Pengenalan Kaedah Pembelajaran Berasaskan Masalah (Problem Base Leanening)

Pembelajaran Berasaskan Masalah merupakan kaedah pembelajaran melalui penyelesaian masalah. Pelajar akan dapat memahami kandungan kursus sepanjang perbincangan bersama ahli kumpulan dalam menyelesaikan masalah yang dikemukakan. Kaedah ini 
menjadikan pelajar lebih berdikari sekaligus membentuk fikiran yang kreatif dan kritis tanpa terikat dengan nota dan pandangan pensyarah. Ia juga dapat mengukuhkan kemahiran pelajar dalam mempelajari sesuatu prinsip, konsep dan menggunakan maklumat dalam pelbagai situasi. Di samping itu memberi ruang kepada pelajar mengaplikasikan pengetuahuan dan kemahiran teknologi terkini dalam pengumpulan dan pemilihan informasi serta pembentangan data dan laporan ilmiah. Pelajar juga belajar bekerja dalam kumpulan yang memerlukan mereka menyumbang idea dan tenaga serta bersifat terbuka semasa perbincangan.

Semasa proses pembelajaran menggunakan kaedah PBL ini pensyarah akan berperanan sebagai fasilitator yang membimbing perbincangan pelajar dalam kelas atau sekiranya perlu di luar kelas serta semasa pembentangan laporan.

Semasa proses pembelajaran menggunakan kaedah PBL ini secara umumnya pelajar dibimbing dengan menggunakan jadual yang dikenali sebagai FILA (rujuk jadual 1).

\begin{tabular}{|c|c|c|c|}
\hline \multicolumn{4}{|c|}{ Jadual FILA } \\
\hline $\begin{array}{l}\text { Fakta } \\
\text { (Facts) }\end{array}$ & Idea(Ideas) & $\begin{array}{c}\text { Isu } \\
\text { Pembelajaran } \\
\text { (Learning issues) }\end{array}$ & $\begin{array}{l}\text { Tindakan } \\
\text { Lanjut } \\
\text { (Action) }\end{array}$ \\
\hline $\begin{array}{l}\text { - Apakah } \\
\text { fakta-fakta } \\
\text { yang ditun- } \\
\text { jukkan se- } \\
\text { cara jelas di } \\
\text { dalam ma- } \\
\text { salah yang } \\
\text { diberikan. } \\
\text { (senaraikan) }\end{array}$ & $\begin{array}{l}\text { - Apakah } \\
\text { id e a - i d e a } \\
\text { berka ita n } \\
\text { hasil dari- } \\
\text { pada fakta } \\
\text { yang telah } \\
\text { dis en a rai- } \\
\text { kan tersebut } \\
\text { (senaraikan) }\end{array}$ & 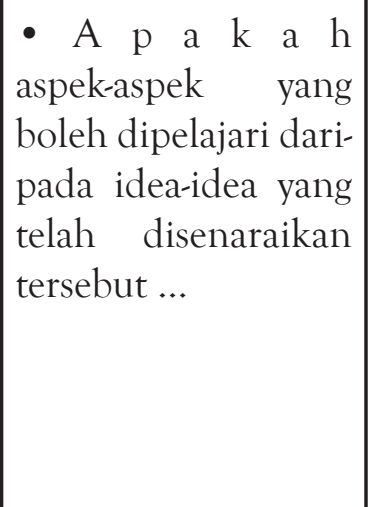 & $\begin{array}{l}\text { - Apa tindak- } \\
\text { an yang perlu } \\
\text { dibuat untuk } \\
\text { pembelajaran } \\
\text { cth: } \\
\text { - Buku-buku } \\
\text { - Observe } \\
\text { - Survey } \\
\text { - Internet } \\
\text { - Video clips }\end{array}$ \\
\hline
\end{tabular}

Jadual 1

Pelajar perlu mengisi jadual tersebut sepanjang membincangkan satu masalah atau trigger yang telah dikenalpasti mempunyai 
hubungan dengan kandungan matapelajaran. Trigger boleh berbentuk gambar, video, keratan akhbar, artikel dan sebagainya. Setelah berjaya mengisi jadual tersebut maka pelajar akan memilih satu isu atau persoalan yang menjadi punca utama bagi masalah tersebut. Isu berkenaan perlu diselesaikan melalui penyelidikan dan penerokaan yang bersistematik. Ketika menjalankan penyelidikan pelajar sekaligus dapat menguasai kandungan matapelajaran.

\section{c. Modul Panduan PBL Untuk dan Pengajian Islam}

Proses pembelajar menggunakan kaedah PBL diperkenal amat sesuai bagi matapelajaran yang berbentuk teknikal dengan jumlah pelajar yang kecil (kurang dari 30 orang). Bagaimanapun Pengajian Islam di UTHM merupakan matapelajaran berasaskan kandungan (content based) yang memerlukan pelajar memahami, mengingat dan menguasai fakta-fakta tertentu. Dalam masa yang sama jumlah pelajar dalam setiap satu pertemuan agak besar (antara 60 hingga 100 orang).

Oleh itu satu modul dibina dengan mengambil kira kekangan yang dihadapi (rujuk jadual II). Modul ini mempunyai serampang dua mata, objektif kaedah PBL dapat dicapai dan kandungan matapelajaran dapat dikuasai oleh pelajar dengan baik.

\begin{tabular}{|l|l|}
\hline \multicolumn{2}{|c|}{ Minggu 1 } \\
\hline \multicolumn{1}{|c|}{ Aktiviti } & \multicolumn{1}{c|}{ Tindakan } \\
\hline $\begin{array}{l}\text { Penerangan silabus mata } \\
\text { pelajaran dan disiplin kelas. }\end{array}$ & Pensyarah \\
\hline $\begin{array}{l}\text { Penerangan pengertian dan } \\
\text { aktiviti PBL. }\end{array}$ & Pensyarah \\
\hline $\begin{array}{l}\text { Pembahagian pelajar kepada 8 } \\
\text { kumpulan (Ice breaking, sesi } \\
\text { pengenalan, pemilihan ketua } \\
\text { kumpulan, kenalpasti peranan } \\
\text { masing-masing.) }\end{array}$ & Ketua dan ahli kumpulan. \\
\hline
\end{tabular}




\begin{tabular}{|c|c|}
\hline $\begin{array}{l}\text { Pengagihan tajuk kuliah min- } \\
\text { ggu } 3 \text { hingga } 10 \text { kepada kum- } \\
\text { pulan untuk dibentang dan } \\
\text { dibincangkan pada minggu } 3 \\
\text { hingga } 10 \text { sebagai tugasan } 1 \text {. }\end{array}$ & Pensyarah dan pelajar \\
\hline $\begin{array}{l}\text { Kuliah dan perbincangan tajuk } \\
\text { minggu } 1\end{array}$ & Pensyarah dan pelajar \\
\hline $\begin{array}{l}\text { Mengadakan perbincangan } \\
\text { dalam kumpulan selama } 2 \text { jam } \\
\text { di luar kuliah. Menyiapkan } \\
\text { bahan pembentangan dan } \\
\text { mendapatkan trigger yang ses- } \\
\text { uai dengan tajuk. Setiap kump- } \\
\text { ulan mesti menghantar laporan } \\
\text { perbincangan dan aktiviti yang } \\
\text { telah dijalankan. }\end{array}$ & Ketua dan ahli kumpulan. \\
\hline \multicolumn{2}{|c|}{ Minggu 2} \\
\hline Aktiviti & Tindakan \\
\hline $\begin{array}{l}\text { Penerangan aktiviti PBL } \\
\text { (penggunaan jadual FILA) }\end{array}$ & Pensyarah \\
\hline Pembentangan trigger. & Ketua dan ahli kumpulan \\
\hline $\begin{array}{l}\text { Kuliah dan perbincangan tajuk } \\
\text { minggu } 2\end{array}$ & Pensyarah dan pelajar \\
\hline $\begin{array}{l}\text { Mengadakan perbincangan } \\
\text { dalam kumpulan selama } 2 \\
\text { jam di luar bilik bilik kuliah. } \\
\text { Menyiapkan bahan pemben- } \\
\text { tangan dan mengisi jadual } \\
\text { FILA. Setiap kumpulan mesti } \\
\text { menghantar laporan perbin- } \\
\text { cangan dan aktiviti yang telah } \\
\text { dijalankan. }\end{array}$ & Ketua dan ahli kumpulan. \\
\hline
\end{tabular}


$82 \frac{\text { Jurnal AL-AFKAR }}{\text { Vol. II, No. II, Oktober } 2013}$

\begin{tabular}{|l|l|}
\hline \multicolumn{2}{|c|}{ Minggu 3 hingga 10 } \\
\hline \multicolumn{1}{|c|}{ Aktiviti } & \multicolumn{1}{c|}{ Tindakan } \\
\hline $\begin{array}{l}\text { Pembentangan dan perbin- } \\
\text { cangan tajuk kuliah mengikut } \\
\text { silabus yang telah ditetapkan. }\end{array}$ & $\begin{array}{l}\text { Ketua dan ahli kumpulan. } \\
\text { Pelajar. }\end{array}$ \\
\hline Ulasan Pensyarah & Pensyarah \\
\hline Pembentangan jadual FILA. & Ketua dan ahli kumpulan. \\
\hline $\begin{array}{l}\text { Perbincangan tajuk untuk } \\
\text { tugasan 2. }\end{array}$ & $\begin{array}{l}\text { Pensyarah, ketua kumpulan, } \\
\text { ahli kumpulan dan pelajar. }\end{array}$ \\
\hline $\begin{array}{l}\text { 2 jam seminggu pembelaja- } \\
\text { ran di luar bilik kuliah untuk } \\
\text { mendapatkan bahan bagi meny- } \\
\text { empurnakan tugasan 2. }\end{array}$ & Ketua dan ahli kumpulan. \\
\hline $\begin{array}{l}\text { Menghantar tugasan 2 satu } \\
\text { minggu sebelum pembentangan } \\
\text { (berpandukan tarikh pem- } \\
\text { bentangan kumpulan). Setiap } \\
\text { kumpulan mesti menghantar } \\
\text { laporan aktiviti yang telah } \\
\text { dijalankan. }\end{array}$ & Ketua dan ahli kumpulan. \\
\hline \multicolumn{2}{|c|}{ Minggu 11 hingga 14 } \\
\hline $\begin{array}{l}\text { Pembentangan dan perbincang- } \\
\text { an tugasan 2. }\end{array}$ & Ketua dan ahli kumpulan. \\
\hline Ulasan Pensyarah & Pensyarah \\
\hline
\end{tabular}

\section{Jadual II}

\section{d. Penerokaan Teknologi Melalui Kaedah PBL}

Melalui kaedah PBL yang menggunakan modul baru tersebut pelajar perlu menyiapkan 2 tugasan dan membuat 2 pembentangan. Dalam menyiapkan tugasan tersebut pelajar diberi kebebasan untuk menggunakan kemudahan teknologi terkini agar ianya dapat dipersembahan dengan baik. 
Bagi tugasan 1 pelajar perlu menyiapkan laporan yang mengandungi maklumat setiap ahli kumpulan seperti; gambar, nama, kursus, no matrik, falsafah hidup dan sebagainya, slide pembentangan yang telah dicetak, bahan-bahan tambahan yang berkaitan tugasan seperti artikel dan gambar, trigger, jadual FILA serta cd rom yang mengandungi semua maklumat tersebut. Didapati tugasan tersebut dapat dipersembahkan dengan baik dan pelajar telah menggabungkan penggunaan teknologi terkini bagi menyiap laporan serta mendapatkan maklumat. Antaranya;

(i) menggunakan rakaman video sebagai trigger, dari 8 kumpulan bagi satu kelas Pengajian Islam kumpulan membentangkan triggers menggunakan rakam video,

(ii) menggunakan blackboard bagi mendapatkan maklumat utama bagai kandungan tugasan,

(iii) melayari internat untuk mendapatkan maklumat tambahan, membuat salinan gambar yang telah diubahsuai dengan menggunakan kemahiran teknologi (contoh: superimpose),

(iv) membuat rakaman gambar dan lakonan serta membuat penyuntingan gambar atau video.

Laporan yang telah siap perlu dibentang secara ringkas dan menarik. Oleh itu pelajar akan menggunakan program-program yang dapat menjadikan kandungan pembentangan menarik dan jelas. Antaranya menggunakan:

(i) flash

(ii) power point

e. Skop Pengajian Islam

Berdasarkan konsep Pengajian Islam yang telah dibincangkan, maka skop pengajian Islam dalam pengajaran dan pembelajaran di Universiti Tun Hussein Onn (UTHM) meliputi: Islam sebagai addeen bersumberkan nas wahyu iaitu al-Qur'an dan al-Sunnah; ii) Sumber rujukan dalam Islam; iii) Pengajian Ulum Al-Quran dan Ulum Al-Hadith; iv) Aqidah Ahli Sunnah wal-Jamaah; v) Aliran pemikiran aqidah dan perbahasannya; vi) Perkembangan mazhab fiqh dan perbahasannya; vii) Prinsip muamalat Islam; viii) Maqasid Syariah dan undang-undang jenayah Islam; ix) Etika kerja Islam; dan $\mathrm{x}$ ) Undang-undang kekeluargaan Islam. Skop pengajian Islam juga me- 
liputi pelbagai isu-isu semasa dan kontemporeri seperti isu murtad, seks luar nikah, aurta menurut Isam, penyalahgunaan dadah, ajaran sesat, penceraian, kes buang bayi, isu syiah, isu negara-negara Islam seperti Mesir, Syiriah, Lubnan dan lain-lainnya.

Dalam hal ini, pembelajaran dan pengajaran subjek Pengajian Islam merupakan asas utama yang bersumberkan pada Al-Quran dan Al-Sunnah. Menurut ajaran Islam, al-Quran ialah yang diturunkan kepada melalui perantaraan yang sampai ke zaman sekarang secara. Perihal diturunkan Al-Quran mempunyai kaitan rapat dengan. AlQuran diturunkan kepada Nabi Muhammad secara beransur-ansur dalam tempoh 23 tahun. Firman Allah SWT dalam surah al-Hijr, ayat 9 :

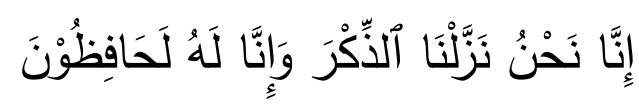

"Sesungguhnya Kamilah yang menurunkan adz-Dzikr (Al-Qur'an), dan kamilah yang akan menjaganya."

Antara aspek yang ditekankan dalam pembelajaran dan pengajaran subjek Pengajian Islam ialah memperkenalkan teori, konsep dan falsafah Pengajian Islam, antara sub subjek yang dipertekankan ialah mengenai sejarah pembukuan Al-Quran dan al-Sunnah. Kitab suci yang diturunkan oleh Allah s.w.t kepada RasulNya Muhammad s.a.w adalah merupakan sebuah kitab yang terkandung di dalamnya wahyu dan pengajaran daripada Allah untuk memandu hidup manusia di dunia dan akhirat. Sebagai nabi dan rasul yang terakhir Nabi Muhammad s.a.w juga menerima wahyu yang terakhir dan kitab al-Qur'an adalah kitab yang terakhir diturunkan oleh Allah kepada manusia. Perkataan "Qur'an" berasal daripada akar kata bahasa Arab qara'a yang bermaksud "baca" dan Qur'an membawa maksud "(bahan) yang dibaca". Bagaimanapun apabila disebut al-Qur'an ianya bukan merujuk kepada sebarang bahan yang boleh dibaca tetapi kepada sebuah kitab yang terkandung di dalamnya " $\mathrm{Ka}$ lam Allah yang diwahyu kepada Nabi Muhammad s.a.w melalui Jibril a.s dalam bentuk makna dan perkataan serta disampaikan kepada manusia dalam bentuk mutawatir secara sebutan dan tulisan, tidak boleh sama sekali ditiru dan terjaga akan kemurniaannya oleh Allah s.w.t hingga hari kiamat." Terdapat nama-nama lain yang dirujuk bagi kitab ini seperti 
al-Furqan (pembeza), al-tanzil (yang diturunkan), al-zikr (pemberi peringatan) dan al-kitab (satu kitab). Gelaran-gelaran lain yang diberi kepada al-Qur'an adalah seperti nur (cahaya), huda (petunjuk), rahmah (memberi kerahmatan), majid (agung), mubarak (yang diberkati), bashir (pemberi berita gembira), nazir (pemberi peringatan) dan lainlain lagi. Kitab al-Qur'an mengandungi 114 surah yang kebiasaannya dirujuk sama ada sebagai surah Makkiyah ataupun Madaniyyah iaitu berdasarkan tempat atau waktu penurunannya. Daripada sejumlah 114 surah tersebut dibahagikan kepada 30 juzuk.

\section{f. Penawaran Kursus}

Secara khususnya, beberapa program ijazah sarjana muda, menawarkan sejumlah subjek yang khusus bertajuk "Pengajian Islam”. Contohnya, program Sarjana Muda Kejuruteraan elektronik dan Sarjana Muda Kejuruteraan Mekanikal menawarkan subjek Pengajian Islam sebagai subjek teras. Dalam buku panduannya, tercatat Rancangan Pembelajaran Pengajaran (RPP) Pengajian Islam sebagai berikut:

\section{a) Matlamat (goals):}

Matlamat pengajaran ini adalah untuk memantap dan mengukuhkan pengetahuan Islam bagi melahirkan modal insan yang berpegang teguh dengan ajaran Islam yang syumul dan mampu melaksanakanya dalam kehidupan secara individu dan kolektif.

b) Sinopsis (synopsis):

Kursus ini menerangkan tentang konsep Islam sebagai al-Deen. Skop perbincangannya meliputi pengajian al-Quran dan al-Hadith; Akidah Ahli Sunnah wal Jamaah; aliran pemikiran akidah; perkembangan mazhab Fiqh; prinsip muamalat; Undang-undang Jenayah Islam; etika kerja dalam Islam; isu-isu dalam Undang-undang kekeluargaan Islam serta isu-isu semasa.

c) Hasil Pembelajaran (learning outcomes):

Setelah mengikuti (kursus ini), pelajar dapat:

(1) menerangkan dengan tepat asas-asas Pengajian Islam menerusi topik-topik yang dipelajari menurut al-Quran dan al-Sunnah (C2:PLO1)

(2) menilai isu-isu semasa berkaitan ajaran sesat, muamalat, jenayah, dan kekeluargaan berdasarkan perspektif Islam (P2:PLO3) 
(3) menunjukkan nilai etika kerja Islam dalam melaksanakan tugasan yang diberi (A3:PLO8)

"Kursus ini membincangkan persoalan yang berkaitan dengan Islam sebagai ad-deen, sumber rujukan Islam, dan pengajian ulum al-Quran dan ulum al-Hadiths. Selain itu, kursus ini juga turut membincangkan mengenai aqidah ahli sunnah wal jamaah, aliran pemikiran aqidah dan perbahasannya, dan perkembangan Mazhab Fiqh dan perbahasannya serta prisip muamalat Islam. Maqasid syariah dan undang-undang jenayah islam, etika kerja dalam Islam, serta undang-undang kekeluargaan Islam juga merupakan persoalanpersoalan lain yang turut dibincangkan dalam kursus ini. Kursus ini juga meliputi pembentangan tugasan yang dilaksanakan secara kerja berkumpulan dalam kalangan pelajar. Selain itu, tercatat beberapa rujukan:

Rujukan Utama :

(1) Harun Din (Dr.) (2001), Manusia Dan Islam, cetakan pertama, Kuala Lumpur: Dewan Bahasa dan Pustaka. (BP174. M36 1990)

(2) Ismail Haji Ali, (1995), Pengertian dan Pegangan Iktikad yang benar: Ahli Sunnah Wal Jamaah: Kuala Lumpur: Penerbitan al-Hidayah. (BP166.78. P46 1995)

(3) Mustafa Abdul Rahman (1998), Hadith 40, Kuala Lumpur: Dewan Pustaka Fajar. (BP135. A2 M87 1998)

(4) Mustafa Haji Daud (1989), Institusi Kekeluargaan Islam, Kuala Lumpur: Dewan Pustaka dan Bahasa. ( (BP188.3. F3.M87 1989)

(5) Paizah Haji Ismail (1991), Undang-undang Jenayah Islam, Kuala Lumpur: Dewan Pustaka Islam, Angkatan Belia Islam Malaysia. (BP144. P35 1991)

Rujukan Lain :

(1) Abdur Rahman I.Doi (1995), Undang-undang Syariah, terjemahan Rohani Abdul Rahim, Kuala Lumpur: Dewan Bahasa dan Pustaka. (BP173.6. A72 1995)

(2) Adnan Alias (2002), Keusahawanan Islam, Kuala Lumpur: Prentice Hall. (BP173.75. A36 2002)

(3) Muhammad Sulaiman Haji Yasin (1988), Pengantar Aqidah, Kuala Lumpur: Dewan Bahasa dan Pustaka. (BP166. M67 1984)

(4) Muhammad Ahmad Abdul Jawwad (2000), Pengurusan Yang Profesional Dalam Islam, Kuala Lumpur: Penerbit Berlian. 
(BP173.77. J39 2004)

(5) Mohammad Muslehudin (1989), Insuran dan Hukum Islam, Kuala Lumpur: Dewan Bahasa dan Pustaka. (BP190.5. I67 M65 1989)

(6) Mustafa Hj. Daud (1996), Tamadun Islam, Kuala Lumpur: Utusan Publications dan Distribution. (D199.3. M88 1999)

(7) Khaliq Ahmad (2006), Managment From Islamic Perspective, Kuala Lumpur: Penerbit UIA. (BP190.5. M28.K42 2006)

Penelitian ini juga mendapati bahawa kajian ini nantinya akan menjadi rujukan penting. Ia juga sudah pasti menjadi rujukan pilihan pertama di kalangan pelajar Melayu-Muslim kerana karya ini akan menjadi Rool Model bagi subjek subjek yang lainnya. Dengan itu, dapat dirumuskan bahawa pemetaan Subjek Pengajian Islam yang dikerangkakan mempunyai pengaruh yang besar terhadap para pelajar yang dapat membina jati diri berteraskan akhlak mulia.

\section{g. Cabaran Pengajian Islam Di UTHM}

Islam adalah agama yang sentiasa menghadapi cabaran. Berikutan itu, segala yang lahir daripada Islam, termasuk pemikirannya dan pegajian pemikiran tersebut, tidak dapat tidak berhadapan dengan cabaran, sama ada dari luar atau dalam. Antara cabaran yang dihadapi oleh Pengajian Islam adalah pemahaman pemahaman terhadap konsep Pengajian Islam dan dan kurangnya penghayatan ilmu pengajian Islam bagi pelajar yang berlatar belakangkan pengajian kejuruteraan, teknikal dan teknologi.

Berkaitan dengan hal ini juga, Pengajian Islam di Malaysia berhadapan dengan cabaran pensyarah yang telah menganut satusatu aliran tertentu dalam pemikiran Islam sama ada dalam konteks klasiknya seperti Syiah atau Muktazilah atau dalam konteks semasanya seperti fundamentalis atau modenis. Dengan itu, pensyarah sedemikian tidak dapat berlaku adil terhadap aliran utama Pengajian Islam di Malaysia dan Nusantara yang berteraskan Sunni tradisionalis. Tambahan pula, pensyarah berkenaan mungkin terjerumus ke dalam perbahasan antara firaq Islam klasik yang mengulang-ngulangi kembali persoalan klasik yang tidak pernah selesai. Selain itu, tidak dinafikan akan muncul amalan pengajaran-pembelajaran yang bersifat pendoktrinasian secara tidak langsung berikutan anutan pensyarah terbabit. Walaupun secara sedar, pensyarah berkenaan su- 


\section{$88 \frac{\text { Jurnal AL-AFKAR }}{\text { Vol. II, No. II, Oktober } 2013}$}

dah pasti tidak mahu melakukan pendoktrinasian kerana ia adalah amalan yang tidak baik dalam pendidikan kerana boleh membawa kepada risiko taklid dan dari suatu sudut lain boleh mengakibatkan keresahan pemikiran di kalangan ahli aliran utama; tetapi, jika dilihat dari suatu sudut lain pula, ia adalah perkara yang baik dalam usaha percambahan pemikiran yang lebih luas.

\section{Penutup}

Berdasarkan keterangan dan penjelasan di atas, Pengajian Islam di UTHM mengambil tempat yang lebih baik, sama ada dari segi sumber, pengajar, pelajar, institusi yang menawarkan dan mendapat sambutan daripada masyarakat awam. Selain daripada bertambahnya bilangan mereka yang berminat mengajar dan belajar serta mengadakan kajian dan penyelidikan mengenainya, bidangnya semakin meluas dalam aspek semasa. 


\title{
Peranan Pendidikan Agama Dalam Keluarga Terhadap Pembentukan Kepribadian Anak-Anak
}

\author{
Nurmadiah \\ Dosen Jurusan Manajemen Pendidikan Islam, Fakultas Ilmu Agama \\ Islam, Universitas Islam Indragiri (UNISI) Tembilahan
}

\begin{abstract}
Abstrak
Dalam kehidupan manusia, pendidikan memiliki peranan penting dalam membentuk generasi mendatang. Dengan pendidikan diharapkan dapat menghasilkan manusia berkualitas, bertanggung jawab dan mampu meng-antisipasi masa depan. Pendidikan dalam maknanya yang luas senantiasa menstimulir, menyertai perubahan-perubahan dan perkembangan umat manusia. Selain itu, upaya pendidikan senantiasa menghantar, membimbing perubahan dan perkembangan hidup serta kehidupan umat manusia. Keluarga merupakan sebuah pondasi dan institusi yang paling dicintai dalam Islam. Untuk menciptakan keluarga yang baik, pendidikan agama memiliki peran penting dalam pembentukannya. Pendidikan agama di lingkungan keluarga sangat besar peranannya dalam pembentukan kepribadian bagi anak-anak, karena di lingkungan keluargalah anak-anak pertama kali menerima pendidikan yang dapat mempengaruhi perkembangan anak selanjutnya. Agar anak-anak memiliki kepribadian yang baik dan terhindar dari pelanggaran-pelanggaran moral, maka perlu adanya pembinaan agama sejak dini kepada anak-anak dalam keluarga. Proses pembinaan nilai-nilai agama dalam membentuk kepribadian anak-anak dapat dimulai sejak anak lahir sampai ia dewasa. Ketika lahir diperkenalkan dengan kata-kata thoyyibah, kemudian setelah mereka tumbuh dan berkembang menjadi anak-anak, maka yang pertama harus ditanamkan ialah nilai-nilai agama yang berkaitan dengan keimanan, sehingga anak meyakini adanya Allah dan dapat mengenal Allah dengan seyakin-yakinnya (ma'rifatullah). Bersamaan dengan itu, anak-anak juga dibimbing mengenai nilai-nilai moral, seperti cara bertutur kata yang baik, berpakaian yang baik, bergaul dengan baik, dan lain-lainnya. Kepada anak-anak juga ditanamkan sifat-sifat yang baik, seperti nilai-nilai kejujuran, keadilan, hidup serderhana, sabar dan lain-lainnya. Selain itu, agar anak-anak memiliki nilai-nilai moral yang baik di dalam keluarga, khususnya antara ibu dan bapak harus menjaga harmonisasi hubungan antara keduanya dan harus menjadi suri tauladan bagi anak-anaknya.
\end{abstract}

Key Words: Pendidikan Agama, Pembentukan kepribadian anak 


\section{A. Pendahuluan}

Disamping peranan pendidikan yang menjadi dasar dalam pembentukan kepribadian anak. Orang tua juga memegang peran yang penting dalam pembentukan kepribadian anak-anak. Baik buruknya kepribadian anak-anak di masa yang akan datang banyak di tentukan oleh pendidikan agama dan bimbingan orang tuanya. Karena didalam keluarga itulah anak-anak pertama kali memperoleh pendidikan sebelum pendidikan-pendidikan yang lain. Sejak anak lahir dari rahim ibunya sampai anak-anaknya dewasa orang tua selalu mendidik, menjaga, merawat mereka dengan penuh kasih sayang dengan harapan kelak mereka dapat tumbuh besar dan berkembang menjadi manusia dewasa yang baik, yang sesuai dengan ajaran agama Islam. Pendidikan yang diberikan di lingkungan keluarga berbeda dengan pendidikan yang diberikan di sekolah, karena pendidikan di lingkungan keluarga bersifat informal, yang tidak terikat oleh waktu dan program pendidikan secara khusus, sebagaimana lembaga pendidikan sekolah.

Pendidikan dalam keluarga berjalan sepanjang masa, melalui proses interaksi dan sosialisasi didalam keluarga itu sendiri. Esensi pendidikannya tersirat dalam integritas keluarga, baik didalam komunikasi antara sesama keluarga, dalam tingkahlaku keseharian orang tua, dan keluarga lainnya,juga dalam hal-hal lainnya yang berjalan dalam keluarga semuanya merupakan proses pendidikan bagi anak-anak. Oleh karena itu orang tua harus selalu memberikan contoh tauladan yang baik bagi anak-anak mereka, karena apapun kebiasaan orang tua di rumah akan selalu dilihat, dicerna dan bahkan sampai akan diritu oleh anak-anak.

Sebagai lingkungan pendidikan yang pertama, keluarga memegang peran yang sangat besar dalam membentuk pola kepribadian anak. Oleh karena itu orang tua sebagai penanggung jawab atas kehidupan keluarga harus memberikan pendidikan dan pengajaran kepada anak-anaknya dengan menanamkan pendidikan agama dan akhlak yang baik dalam kehidupan sehari-hari.

Sejalan dengan semakin pesatnya era globalisasi yang dicirikan dengan derasnya arus informasi dan teknologi, ternyata dari satu sisi memunculkan persoalan-persoalan baru yang kerap kali kita temukan pada diri individu dalam suatu masyarakat. Munculnya kenal- 
akan remaja, tawuran antar pelajar, narkoba, penyimpangan seksual, kekerasan antara anak-anak, terkadang sampai anak tega menyakiti orang tuanya sendiri, serta berbagai bentuk penyimpangan penyakit kejiwaan, seperti stres, depresi, dan kecemasan, bahkan sampai bunuh diri. Adalah bukti yang tidak bisa dinafikan ditengah-tengah masyarakat kita sekarang ini, yang merupakan dampak negatif dari kemajuan peradaban kita. Hal ini secara tidak langsung berpengaruh tidak baik pula pada kemapanan dan tatanan masyarakat damai seperti yang kita harapkan semua.

Masalah kepribadian merupakan suatu masalah yang menjadi perhatian orang dimana saja, baik dalam masyarakat yang telah maju maupun bagi masyarakat yang masih terbelakang. Karena kerusakan moral seseorang merupakan ciri kepribadian orang tersebut dan dapat mengganggu ketentraman orang lain. Jika didalam suatu masyarakat banyak yang rusak moralnya, maka akan tidak amanlah keadaan masyarakat tersebut.

Jika kita tinjau keadaan masyarakat di Indonesia terutama di kota-kota besar sekarang ini, akan kita dapati bahwa sebagian anggota masyarakat memiliki kepribadian yang buruk. Dimana kita lihat, kepentingan umum tidak lagi menjadi nomor satu, akan tetapi kepentingan dan keuntungan pribadilah yang menonjol pada banyak orang.

Kejujuran, keberanian, keadilan, dan kebenaran telah tertutup oleh penyelewengan-penyelewengan,baik yang terlihat ringan maupun berat. Banyak terjadi adu domba, hasud dan fitnah, menjilat, menipu, berdusta, mengambil hak orang lain sesuka hati, disamping juga perbuatan-perbuatan maksiat lainnya.

Orang-orang yang dihinggapi kepribadian buruk, tidak saja orang yang telah dewasa, akan tetapi sudah menjalar sampai kepada generasi muda yang kita harapkan untuk menjadi generasi penerus untuk melanjutkan perjuangan membela nama baik bangsa dan negara kita. Belakangan ini kita banyak mendengar keluhan-keluhan orang tua, para pendidik, dan orang-orang yang berkecimpung dalam bidang sosial dan agama, anak-anak yang terutama berumur belasan tahun dan mulai remaja, mulai sulit dikendalikan, nakal, keras kepala, suka melawan, berbuat keonaran, maksiat, narkoba, bahkan akhir-akhir ini anak-anak sekolah berani melemparkan air 


\section{$92 \frac{\text { Jurnal AL-AFKAR }}{\text { Vol. II, No. II, Oktober } 2013}$}

keras ke penumpang bus yang terjadi di Jakarta, dan hal-hal yang mengganggu ketentraman umum.

Buruknya kepribadian yang disebutkan di atas mencerminkan kelakuan anak-anak yang menggelisahkan orang tuanya sendiri bahkan sampai meresahkan masyarakat yang ada di sekitar keberadaan anak-anak tersebut. Baik yang berkaitan masyarakat sekolah, maupun masyarakat umum, bahkan sampai ada yang menggelisahkan dirinya sendiri. Tidak sedikit orang tua yang mengeluhkan kebingungan menghadapi anak-anak yang tidak bisa lagi dikendalikan baik orang tuanya sendiri maupun oleh guru-gurunya. Contoh-contoh dalam hal ini sangat banyak, kita saksikan dan kita perhatikan sendiri dan kiranya tidak perlu kita paparkan disini.

Berdasarkan uraian di atas, perlu kiranya kita memikirkan tentang model pendidikan anak-anak di lingkungan keluarga, sehingga anak-anak remaja kita memiliki kepribadian yang baik yang akan berdampak pula ke depan terhadap bangsa ini.

Pembahasan dalam materi ini dimaksudkan untuk mengetahui: (1) peranan keluarga bagi anak-anak, (2) faktor-faktor yang menyebabkan memiliki kepribadian yang buruk, (3) peranan pendidikan agama dalam lingkungan keluarga terhadap pembentukan kepribadian anak.

\section{B. PEMBAHASAN}

\section{a. Peranan Keluarga Bagi Anak}

Keluarga secara etimologis berasal dari rangkaian kata "kawula" dan "warga". kawula artinya abdi yakni hamba, sedangkan warga artinya anggota. Sebagai abdi didalam keluarga, seorang wajib menyerahkan segala kepentingannya kepada keluarganya dan warga atau anggota. Ia berhak untuk ikut mengurus segala kepentingan di dalam keluarganya. ${ }^{1}$

Sedangkan menurut M. I Sulaiman, ${ }^{2}$ ciri hakiki suatu keluarga adalah bahwa keluarga itu merupakan: "satu persekutuan hidup yang dijalin kasih sayang antara pasangan dua jenis manusia yang dikukuhkan dengan pernikahan, yang bermaksud untuk saling me-

1 Ihat Hatimah dkk, Pembelajaran Berwawasan Masyarakat, (Jakarta: Universitas terbuka; 2007), hal. 34

2 M.I. Seolaeman, Pendidikan dalam Keluarga. Diktat Kuliah(1978), hal. 12 
nyempurnakan diri”.

Dalam ensyclopedi umum yang dimaksud dengan keluarga yaitu kelompok orang yang ada hubungan darah atau perkawinan yang terdiri dari ibu, ayah, anak-anaknya ( yang belum memisahkan diri sebagai keluarga).

Dalam bahasa Inggris kata keluarga di artikan dengan family. Everet wilson mengartikan family (keluarga) adalah "the face to face group" (kelompok tatap muka). Dia mengartikan lebih ke arah fungsi keluarga.

Keluarga merupakan unit terkecil dalam masyarakat, yang terdiri dari ayah, ibu, anak-anak, dan kerabat lainnya. Lingkungan keluarga merupakan tempat dimana anak-anak di besarkan dan merupakan lingkungan pertama kali dijalani oleh seorang anak dalam mengarungi hidupnya, sehingga apa yang dilihat dan dirasakan oleh anak-anak dalam keluarga akan dapat mempengaruhi pertumbuhan dan perkembangan jiwa seorang anak. ${ }^{3}$

Keluarga merupakan unit pertama dan institusi pertama dalam masyarakat dimana hubungan-hubungan yang terdapat didalamnya, sebahagian bersifat hubungan langsung dan disitulah berkembang individu dan disitu pulalah terbentuknya tahap-tahap awal proses sosialisasi bagi anak-anak. Dari interaksi dalam keluarga inilah anak-anak memperoleh pengetahuan, keterampilan, nilai-nilai, dan sikapnya dalam hidup dan dengan itu pulalah mereka memperoleh ketenangan dan ketentraman hidup.

Pembentukan keluarga dalam Islam bermula dengan terciptanya hubungan suci yang menjalin seorang laki-laki dan seorang perempuan, melalui perkawinan yang halal, memenuhi rukun-rukun dan syarat-syarat sahnya perkawinan tersebut. Oleh karena itu, kedua suami istri itu merupakan unsur utama dalamkeluarga. Jadi, keluarga dalam pengertiannya yang sempit merupakan suatu unit sosial yang terdiri dari seorang suami dan seorang istri, atau dengan kata lain, keluarga adalah perkumpulan yang halal antara seorang laki-laki dan seorang perempuan yang bersifat terus menerus dimana yang satu merasa tentram dengan yang lain sesuai dengan yang ditentukan oleh agama dan masyarakat. Dan ketika kedua suami istri itu

3 Rohmat Mulyana,Cakrawala Pendidikan Umum, Bandung: Ikatan Mahasiswa dan Alumni Pendidikan Umum (IMA-PU) PPS IKIP Bandung; 1999), hal. 42 
dikaruniai anak, maka anak-anak itu merupakan unsur utama ketiga pada keluarga tersebut disamping dua unsur utama sebelumnya.

Keluarga merupakan lingkungan pertama bagi setiap individu dimana dia berinteraksi. Dari interaksi dengan lingkungan pertama inilah individu memperoleh ciri-ciri dan unsur-unsur dasar dalam kepribadiannya. Juga dari situlah dia memperoleh akhlak, nilai-nilai, kebiasaan dan emosinya dan dengan itu dia merubah banyak kemungkinan-kemungkinan, kesanggupan-kesanggupan dan kesediaannyamenjadi kenyataan dalam hidupdan tingkahlaku yang tampak. Jadi keluarga itu bagi seorang individu merupakan simbol atas nilai-nilai yang mulia, seperti keimanan yang teguh kepada Allah, pengorbanan, kesediaan berkorban untuk kepentingan kelompok, cinta kepada kebaikan, kesetiaan, dan nilai-nilai lainnya yang mulia, yang dengannya keluarga dapat menolong individu untuk menanamkannya pada dirinya. ${ }^{4}$

Individu itu perlu pada keluarga bukan hanya pada tingkat awal kehidupnya dan pada masa kanak-kanak, tetapi dia memerlukannya sepanjang hidupnya, karena didalam keluargalah baik anakanak, remaja, orang dewasa, orang tua, dan manula mendapatkan rasa kasih sayang, rasa tentram, dan ketenangan.

Keberadaan keluarga bukan hanya penting bagi seorang individu tetapi juga bagi masyarakat, sehingga masyarakat menganggap keluarga sebagai institusi sosial penting dan merupakan unit sosial yang utama melalui individu-individu yang telah dipersiapkan didalamnya, baik berupa kebudayaan, nilai-nilai, kebiasaan, maupun tradisi yang ada didalamnya. Dari segi inilah, maka keluarga dapat menjadi ukuran dalam sebuah masyarakat, dalam arti apabila masing-masing keluarga berada dalam keluarga yang sehat, maka akan sehatlah suatu masyarakat, dan begitu pula sebaliknya, jika keluarga itu tidak sehat, maka dampaknya terhadap keluarga pun akan menjadi tidak sehat.

Keluarga sebagai tempat dimana anak-anak dibesarkan memiliki peranan yang sangat penting dalam pendidikan anak, karena pertama-tama yang akan dilihat dan dirasakan oleh anak sebelum orang lain adalah keluarga. Pendidikan keluarga tidak akan tergeser

4 Djahiri. A. K, Menelusuri Dunia Efektif, pendidikan Nilai dan Moral, Bandung: Lab. PMP IKIP; 1966), hal. 19 
oleh banyaknya institusi-institusi dan lembaga-lembaga pendidikan yang ada, seperti Taman Kanak-Kanak, Sekolah-sekolah, akademi-akademi dan lain-lainnya. Begitu juga dengan bertambahnya lembagalembaga kebudayaan, kesehatan, politik, agama tidak akan menggeser fungsi kedudukan keluarga.

Walaupun begitu tingginya tingkat perkembangan dan perubahan yang berlaku disebahagian besar masyarakat modern, termasuk masyarakat muslim sendiri, tetapi keluarga tetap memelihara fungsi pendidikannya dan menganggap bahwa hal itu merupakan sebagian tugasnya, khususnya dalam rangka menyiapkan sikap cinta mencintai dan keserasiaan diantara anggota-anggotanya. Begitu juga ia harus memberi pemeliharaan kesehatan, psikologikal, spiritual, akhlak, jasmani, intelektual, emosional, dan sosial disamping menolong mereka menumbuhkan pengetahuan, ketrampilan, sikap dan kebiasaan, yang diingini yang berguna bagi segala lapangan hidup mereka serta sanggup mengambil pelajaran dari lembaga-lembaga lain..$^{5}$

Peranan pendidikan yang sepatutnya di pegang oleh keluarga bagi anggota-anggotanya secara umum adalah peranan yang paling pokok dibanding peranan-peranan lainnya.Lembaga-lembaga lain dalam masyarakat, misalnya lembaga politik, ekonomi, kebudayaan dan lain-lain tidak dapat memegang peranan itu. Walaupun lembagalembaga lain dapat menolong keluarga dalam tindakan pendidikan, akan tetapi ia tidak sanggup untuk menggantikannya, kecuali dalam keadaan-keadaan luarbiasa. Seperti ibu bapak meninggal atau ibu bapak rusak akhlak dan menyeleweng dari kebenaran, atau mereka acuh tak acuh dan tidak tahu cara mendidikan anak dengan benar. Orang tua semacam ini tidak akan sanggup mendidik anak-anaknya menjadi orang terhormat dan baik. Karenanya akan menjadi mashlahat apabila anak-anak itu dididik di luar keluarga mereka. Misalnya dalam institusi-institusi yang baik, teratur dan bertanggung jawab atas baik dan buruknya kepribadian. ${ }^{6}$

5 Ibid., Hal. 31

6 Rohmat Mulyana, Mengartikulasikan Pendidikan Nilai, (Bandung: Alfabeta; 2004), hal. 24 
Menurut Syamsu Yusuf, ${ }^{7}$ keluarga dipandang sebagai penentu utamapembentukan kepribadian anak. Alasannya adalah: (1) keluarga merupakan kelompok sosial pertama yang menjadi pusat indentifikasi anak, (2) anak banyak menghabiskan waktunya di lingkungan keluarga, dan (3) para anggota keluarga merupakan "significant people" bagi pembentukan kepribadian anak.

Di samping itu keluarga juga dipandang sebagai lembaga yang dapat memenuhi kebutuhan insani, terutama bagi pengembangan kepribadiannyadan pengembangan ras manusia. Melalui perlakukan dan perawatan yang baik dari orang tua, anak dapat memenuhi kebutuhannya, baik kebutuhan fisik-biologis, maupun kebutuhan sosio psikologisnya. Apabila anak dapat memenuhi kebutuhan-kebutuhan dasarnya, maka dia cenderung berkembang menjadi seorang pribadi yang sehat.

Perlakukan orang tua yang penuh kasih sayang dan pendidikan nilai-nilai kehidupan, baik nilai agama maupun nilai budaya sosial yang diberikan kepada anakmerupakan faktor yang kondusif untuk mempersiapkan anak menjadi pribadi dan warga masyarakat yang sehat dan produktif.

Suasana keluarga sangat penting bagi perkembangan kepribadian anak, seorang anak yang dibesarkan dalam lingkungan keluarga yang harmonis dan agamis, yaitu suasana yang memberikan curahan kasih sayang, perhatian, dan bimbingan dalam bidang agama, maka perkembangan kepribadian anak tersebut cenderung positif dan sehat. Sedangkan anak yang dikembangkan dalam lingkungan keluarga yang berantakan, tidak harmonis, keras terhadap anak dan tidak memperhatikan nilai-nilai agama, maka perkembangan kepribadiannya cenderung mengalami distorsi atau mengalami kelainan dalam penyesuaian dirinya.

Apabila fungsi keluarga dalam kajian psikologikal modern menekankan pendidikannya pada pembinaan jiwa mereka dengan rasa cinta, kasih sayang,dan ketentraman, justru para ahli jiwa muslim jauh sebelum itu telah menekankan perkara ini dalam berbagai tulisannya. Ulama-ulama muslim dahulu kala menekankan pentingnya peranan pendidikan keluarga itu pada tahun-tahun pertama usia anak-anak yang berdasarkan pada pengalaman-pengalaman mereka

7 Syamsu yusuf, Meretas Pendidikan Nilai, (Bandung: Arfino Raya; 2007), hal. 15 
sendiri. Disamping itu, nash-nash al-Qur'an dan as-Sunnah banyak yang menekankan pentingnya pendidikan dalam keluarga. Di antaranya Allah swt. berfirman, "Peliharalah dirimu dan keluargamu dari api neraka." (QS.66:6). Juga Rasulullah saw. bersabda, "Setiap bayi yang dilahirkan dalam keadaan fitrah, maka ibu bapaknya lah yang menjadikan dia Yahudi, Nasrani, atau Majusi (HR. At-Tabrani dan Baihaqi). Dalam sabdanya yang lain, Rasulullah menjelaskan, "Awasi lah anak-anakmu dan perbaikilah adabnya." (HR. Ibnu Majah)

Dari bukti-bukti yang dikemukakan di atas, menunjukkan bahwa mendidik anak dalam keluarga kewajiban paling utama. Kewajiban ini tidak dapat ditinggalkan kecuali karena udzur, dan tidak akan membebaskan dia dari tanggung jawab ini dengan adanya institusi-institusi pendidikan yang didirikan khusus untuk anak-anak dan generasi muda. Sebab institusi itu tidak akan sanggup mengganti keluarga dalam menanamkan rasa cinta dan kasih sayang kepada anak-anak.

Keluarga merupakan pendidik utama dan pertama, pertama karena lingkungan awal sebelum anak itu mengenal luar dan utama karena keluarga menjadi lingkungan sosial dan emosional dimana hal itu sangat memberikan kualitas pengalaman sehingga menjadi faktor determinan untuk pembentukan kepribadian seorang anak. ${ }^{8}$

Menurut M.I. Sulaiman, ${ }^{9}$ fungsi keluarga itu ada delapan jenis yaitu: (1) fungsi edukasi, (2) fungsi sosialisasi, (3) fungsi proteksi, (4) fungsi afeksi, (5) fungsi religius, (6) fungsi ekonomi, (7) fungsi rekreasi, (8) fungsi biologis.

Berdasarkan pada beberapa fungsi di atas, terlihat bahwa salah satu fungsi keluarga adalah fungsi pendidikan. Hal ini berarti bahwa orang tua sebagai pendidik utama dan pertama mempunyai kewajiban dalam memberikan pendidikan kepada anak-anaknya termasuk pendidikan nilai moral pada anaknya.

\section{b. Faktor-Faktor yang Mempengaruhi Kepribadian}

Kepribadian yang dimiliki seseorang tidak lepas dari pengaruh yang datang dari luar dirinya. Paling tidak ada tiga faktor utama

8 Abdullah Nasih Ulwan, Pendidikan Anak dalam Islam, (Jakarta: pustaka Imani; 2007), hal. 57

9 M.I. Seolaeman. Op. Cit., hal. 84 


\section{$98 \frac{\text { Jurnal AL-AFKAR }}{\text { Vol. II, No. II, Oktober } 2013}$}

yang bekerja didalam menentukan perkembangan kepribadian seseorang. Pertama, pengaruh keturunan individu, kedua, pengalaman awal didalam keluarga, ketiga, peristiwa-peristiwa penting di kemudian hari di luar lingkungan rumah. Dengan demikian, pola kepribadian bukanlah hasil belajar secara eksklusif. Sebaliknya, itu berasal dari interaksi dari keduanya. ${ }^{10}$

Kepribadian yang dimiliki seseorang tidak bisa lepas dari faktor keturunan, terutama yang berkaitan dengan pematangan karakteristik fisik dan mental. Meskipun faktor lingkungan sosial dan lainnya besar pengaruhnya terhadap kepribadian, namun tidak lepas dari potensi yang ada dalam individu. Bahan baku utama kepribadian, sepertti fisik, kecerdasan, dan tempramen adalah hasil dari keturunan. Anak memiliki warisan-warisan sifat bawaan yang berasal dari kedua orang tuanya, merupakan potensi tertentu yang terbentuk dan sukar dirubah. Menurut H.C. Whiterington dalam Uyoh Sa'dullah, ${ }^{11}$ heriditas adalah proses penurunan sifat-sifat atau ciri-ciri tertentu dari suatu generasi ke generasi lain dengan perantaraan sel benih. Pada dasarnya yang diturunkan itu adalah struktur tubuh. Jadi, apa yang diturunkan orang tua kepada anak-anaknya berdasarkan kepada perpaduan gen-gen yang pada umumnya hanya mencakup sifat atau ciri-ciri struktur individu. Yang diturunkan itu sangat kecil menyangkut ciri atau sifat orang tua yang diperoleh dari linggkungan atau hasi belajar dari lingkungannya. Beberapa ciri atau sifat orang tua yang kemungkinan dapat diturunkan, misalnya; warna kulit, kecerdasan, bentuk fisik seperti, bentuk mata, hidung dan lain sebagainya yang berkaitan dengan struktur fisik individu.

Selain dipengaruhi oleh faktor keturunan, kepribadian juga terbentuk dari interaksi figur yang signifikandari semua anggota keluarga (pertama ibu, kemudian ayah dan saudara, dan kemudian figurkeluarga yang lainnya) dengan anak. Anak itu membawa kepada interaksi ini, seperti konstitusi biologis tertentu, kebutuhan tertentu, dan kapasitas intelektual tertentu yang menentukan reaksinya dengan cara dimana dia menindaklanjuti figur yang signifikan tersebut.

10 Linda N.Eyre Richard, Teaching Your Children Values, (New York: Simon Sand Chuster; 1995), hal. 24

11 Uyoh Sa'dullah (2007:65) 
Dalam interaksi antara faktor dan lingkungan, individu memilih dari lingkungannya apa yang sesuai dengan kebutuhan dan keinginan dan menolak apa yang tidak disukainya. Oleh karena itu, pola kepribadian berkembang dimulai dari interaksi dengan lingkungan sendiri.

Selanjutnya, pengakuan keterbatasan yang dikenakan oleh keturunan menggaris bawahi fakta bahwa orang tidak benar-benar bebas untuk memilih dan mengembangkan jenis pola kepribadian yang mereka inginkan denganmenggunakan kecerdasan. Sebagai ilustrasi: seseorang dengan kecerdasan tingkat rendah tidak dapat mengembangkan pola kepribadian seorang pemimpin meskipun ia ingin melakukannya dan walaupun keinginannya memberinya motivasi yang kuat untuk coba mengembangkan ciri kepribadian yang penting untuk kepemimpinannya.

Pendidikan dalam berbagai bentuk, khususnya atau belajar di bawah bimbingan dan arahan yang lain, memainkan peran utama dalam pengembangan pola kepribadian. Sikap terhadap diri, model karakteristik menanggapi orang dan situasi, sikap terhadap asumsi peran sosial yang disetujui, dan metode penyesuaian pribadi dan sosial,termasuk penggunaan mekanisme pertahanan, dipelajari melalui pengulangan dan diperkuat oleh kepuasan yang mereka bawa. Secara bertahap, konsep diri dibangun dan tanggapan belajar menjadi kebiasaan, yang menjadi ciri dalam pola kepribadian individu.

Ada dua alasan, mengapa pendidikan memainkan peran dalam pengembangan pola kepribadian, yaitu; pertama, ia memberi tahu kita bahwa pengendalian dapat dilaksanakan untuk memastikan bahwa individu akan mengembangkan jenis pola kepribadian yang akan dapat menyesuaikan pribadi dan sosial yang baik. Kedua, hal itu mengatakan kepada kita bahwa konsep diri yang tidak sehat dan pola sosial tidak dapat diterima penyesuaiannya dapat diubah dan dimodifikasi. Seperti dalam mempelajari semua, semakin cepat perubahan atau modifikasi dicoba, akan semakin mudah.

\section{c. Faktor-Faktor Penyebab Anak Berpribadi Buruk}

Apabila kita analisis faktor-faktor yang menyebabkan anakanak memiliki kepribadian buruk, sehingga mengakibatkan merosot- 
nya moral pada masyarakat banyak sekali. Menurut Zakiyah Drajat ${ }^{12}$ (1988:84), antara lain yang terpenting adalah :

1. Kurang tertanamnya jiwa agama pada tiap-tiap orang dalam masyarakat

Keyakinan beragama yang didasarkan ataspengertian yang sungguh-sungguh dan sehat tentang ajaran agama yang dianutnya, kemudian diringi dengan pelaksanaan ajaran-ajaran tersebut merupakan benteng moral yang paling kokoh. Apabila keyakinan beragama itu betul-betul telah menjadi bagian integral dari kepribadian seseorang, maka keyakinannya itulah yang akanmengawasi segala tindakan, perkataan bahkan perasaannya. Jika terjadi tarikan orang kepada sesuatu yang kelihatannya menyenangkan dan menggembirakan, maka keimanannya cepat bertindak meneliti apakah hal tersebut boleh atau terlarang dalam agama.

Jika setiap orang kuat keyakinannya kepada Tuhan, mau menjalankan agama dengan sungguh-sungguh, maka tidak perlu polisi, tidak perlu pengawasan yang ketat, karena setiap orang dapat menjaga dirinya sendiri, tidak mau melanggar hukumhukum dan ketentuan Tuhannya. Semakin jauh masyarakatdari agama, semakin sulit menjaga moral orang dalam masyarakat itu, dan semakin kacaulah suasana, karena semakin banyaknya pelanggaran-pelanggaran atas hak dan hukum.

2. Keadaan masyarakat yang kurang stabil, baik dari segi ekonomi, sosial, dan politik

Faktor kedua yang ikut mempengaruhi moral masyarakat ialah kurang stabilnya keadaan, baik ekonomi, sosial, maupun politik. Kegoncangan atau ketidakstabilan suasana yang melingkungi seseorang menyebabkan gelisah dan cemas, akibat tidak dapatnya mencapai rasa aman dan ketentraman dalam hidup. Demikian juga dengan keadaan sosial dan politik, jika tidak stabil, maka akan menyebabkan orang merasa takut, cemas, dan gelisah dan keadaan seperti ini akan mendorong pula pada kelakuan-kelakuan yang mencari rasa aman yang kadang-kadang menimbulkan kecurigaan, tuduhan-tuduhan yang tidak berala-

12 Zakiyah Drajat, Membina Nilai-nilai Moral di Indonesia, (Jakarta: Bulan Bintang; 1988), hal. 84 
san, kebencian kepada orang lain, adu domba, fitnah, dan lain sebagainya. Hal ini semua mudah terjadi pada orang yang kurang keyakinannya kepada agama, dan mudah menjadi gelisah.

3. Pendidikan moral tidak terlaksana menurut semestinya, baik di rumah tangga, sekolah, dan masyarakat

Faktor ketiga yang juga cukup penting adalah tidak terlaksannya pendidikan moral dengan baik dalam rumahtangga, sekolah, dan masyarakat.Pembinaan moral seharusnya dilaksanakan sejak anak kecil sesuai dengan kemampuan dan umurnya. Karena setiap anak lahir belum mengerti mana yang benar dan mana yang salah, dan belum tahu batas-batas dan ketentuan moral yang berlaku dalam lingkungannya. Tanpa di biasakan menanamkkan sikap-sikap yang dinaggap baik untuk pertumbuhan moral, anak-anak akan dibesarkan tanpa mengenal moral itu. Juga perlu diingat bahwapemahaman tentang moral belum dapat menjamin tindakan moral. Moral bukanlah suatu pelajaran atau ilmu pengetahuan yang dicapai dengan mempelajari tanpa membiasakan hidup bermoral dari kecil, karena moral itu tumbuh dari tindakan kepada pengertian. Disinilah peranan orang tua, guru, dan lingkungan yang sangat penting. Jika anak dilahirkan dan dibesarkan oleh orang tua yang tidak bermoral atau tidak tahu cara mendidik yang baik, ditambah lagi dengan keadaan masyarakat yang goncang dan kurang mengindahkan moral, maka sudah barang tentu hasil yang akan terjadi tidak menggembirakan dari segi moral.

4. Suasana rumah tangga yang kurang baik

Faktor yang terlihat pula dalam masyarakat sekarang adalah kerukunan hidup dalam rumah tangga kurang terjamin. Tidak tampak adanya saling pengertian,saling menerima, saling menghargai, saling mencintai diantara suami istri. Tidak rukunnya ibu bapak menyebabkan gelisahnya anak-anak, mereka menjadi takut,cemas, dan tidak tahan tinggal berada ditengahtengah orang tua yang tidak rukun. Maka anak-anak yang gelisah dan cemas itu mudah terdorong pada perbuatan-perbuatan yang merupakan ungkapan dari rasa hatinya, bosannya akan mengganggu ketentraman orang lain. Demikian juga halnya dengan anak-anak yang merasa kurang mendapat perhatian, kasih say- 
ang, dan pemeliharaan orang tua akan mencarikepuasan di luar rumah.

5. Diperkenalkannya secara populer obat-obat dan alat-alat anti hamil

Suatu hal yang sementara pejabat tidak sadari bahayanya terhadap moral anak-anak muda adalah diperkenalkannyasecara populer obat-obatan dan alat-alat yang digunakan untuk mencegah kehamilan. Seperti kita ketahui bahwa usia muda adalah usia yang baru mengalami dorongan seksual akibat pertumbuhan biologis yang dilaluinya, mereka belum mempunyai pengalaman, dan jika mereka juga belum mendapatkan didikan agama yang mendalam, mereka akan dengan mudah dibujuk oleh orangorang yang tidak baik, yang hanya melampiskan hawa nafsunya. Dengan demikian, akan terjadilah obat atau alat itu digunakan oleh anak-anak mudayang tidak terkecuali anak-anak sekolah atau mahasiswa yang dapat dibujuk oleh orang yang tidak baik itu, oleh karena kemauan mereka sendiri yang mengikuti arus darah mudanya, tanpa terkendali. Orang tidak ada yang tahu, karena bekasnya tidak terlihat dari luar.

6. Banyaknya tulisan, gambar, siaran, kesenian dan permainan yang tidak mengindahkan dasar-dasar dan tuntunan moral

Suatu hal yang belakangan ini kurang mendapat perhatian kita adalah tulisan-tulisan, bacaan-bacaan, lukisan-lukisan, siaran-siaran, kesenian-kesenian, dan permainan-permainan yang seolah-olahmendorong anak muda untuk mengikuti arus mudanya. Segi-segi moral dan mental kurang mendapat perhatian, hasil-hasil seniitu sekedar ungkapan dari keinginan dan kebutuhan yang sesungguhnya tidak dapat dipenuhi begitu saja. Lalu digambarkan dengan sangat realistis, sehingga semua yang tersimpan didalam hati anak-anak muda diungkap dan realisasinya terlihat dalam cerita, lukisan, atau permainan tersebut. Inipun mendorong anak-anak mudake jurang kemerosotan moral.

7. Kurang adanya bimbingan untuk mengisi waktu luang dengan cara yang baik, dan yang membawa kepada pembinaan moral

Suatu faktor yang juga telah ikut memudahkan rusaknya moral anak-anak muda ialah kurangnya bimbingan dalam mengisi waktu luang dengan yang baik dan sehat. Umur muda 
adalah umur yang suka berkhayal, melamunkan hal yang jauh. Kalau mereka dibiarkan tanpa bimbingan dalam mengisi waktunya, maka akan banyak lamunan dan kelakuan yang kurang sehat timbul dari mereka.

8. Tidak ada atau kurangnya markas-markas bimbingan dan penyuluhan bagi anak-anak dan pemuda-pemuda

Terakhir perlu dicatat, bahwa kurangnya markas bimbingan dan penyuluhan yang akan menampung dan menyalurkan anak-anak ke arah mental yang sehat. Dengan kurangnya atau tidak adanya tempat kembali bagi anak-anak yang gelisah dan butuh bimbingan itu, maka pergilah mereka berkelompok dan bergabung dengan anak-anak yang juga gelisah. Dari sini akan keluarlah model kelakuan yang kurang menyenangkan.

\section{d. Peranan Pendidikan Terhadap Pembentukan Kepribadian}

Setelah kita mengetahui penyebab anak-anak memiliki kepribadian buruk yang mengakibatkan merosotnya moral seperti yang diuraikan di atas, menunjukkan betapa pentingnya pendidikan agama bagi anak-anak kita, dan betapa pula besarnya bahaya yang terjadi akibat kurangnya pendidikan agama itu. Untuk itu perlu kiranya kita mencari jalan yang dapat mengantarkan kita pada terjaminnya kepribadian anak-anak yang kita harapkan menjadi warga negara yang cinta akan bangsa dan tanah airnya, dapat menciptakan dan memelihara ketentraman dan kebahagiaan masyarakat dan bangsa dikemudian hari.

Keluarga memiliki peranan yang sangat penting dalam pendidikan agama bagi anak-anaknya, terutama dalam pembentukan kepribadian. Menurut M.I Soelaeman (1978:66), salah satu fungsi keluarga adalah fungsi religius.Artinya keluarga berkewajiban memperkenalkan dan mengajak anak dan anggota keluarga lainnya kepada kehidupan beragama. Untuk melaksanakannya, orang tua sebagai tokoh-tokoh inti dalam keluarga itu terlebih dahulu harus menciptakan iklim religius dalam keluarga itu, yang dapat dihayati oleh seluruh anggotanya, terutama dengan anak-anaknya.

Pendidikan agama harus dimulai sejak dini, terutama dalam keluarga, sebab anak-anak pada usia tersebut siap untuk menerima ajaran agama yang berkaitan dengan keimanan kepada Allah tanpa 


\section{$104 \frac{\text { Jurnal AL-AFKAR }}{\text { Vol. II, No. II, Oktober } 2013}$}

harus menuntut dalil yang menguatkannya. Dalam pendidikan usia dini, ia juga tidak berkeinginan untuk memastikan atau membuktikan kebenaranajaran agama yang diterimanya.

Dalam penanaman pendidikan agama di lingkungan keluarga yang harus diberikan kepada anak-anak tidak terbatas kepada masalah ibadah,seperti sholat, zakat, puasa, mengaji, tetapi harus mencakup keseluruhan hidup, sehingga menjadi pengendali dalam segala tindakan. Bagi orang yang menyangka bahwa agama sempit, maka pendidikan agama terhadap anak-anak dianggap cukup dengan memanggil guru ngaji ke rumah atau menyuruh anaknya mengaji ke madrasah atau ke tempat lainnya. Padahal yang terpenting dalam penanam jiwa adalah didalam keluarga, dan harus terjadi melalui pengalaman hidup seorang anak dalam keluarga. Apa yang dilihat, dirasakan, dan didengar oleh anak sejak ia kecil akan mempengaruhi kepribadiannya.

Supaya pembinaan nilai-nilai agama itu betul-betul membuat kuatnya jiwaanak-anak untuk menghadapi tantangan segala zamandan suasana dikemudian hari, hendaknya ia dapat terbina sejak lahir, bahkan sejak dalam kandungan sampai ia mencapai usia dewasa dalam masyarakat.

Hasan Langgulung, ${ }^{13}$ mengemukakan bahwa pendidikan agamadan spiritual termasuk bidang-bidang pendidikan yang harusmendapat perhatian penuh oleh keluarga terhadap anak-anaknya. Pendidikan agama dan spritual ini berarti membangkitkan kekuatan dan kesediaan spiritual yang bersifat naluri yang ada pada anak-anak melalui bimbingan agama yang sehat dan mengamalkan ajaran-ajaran agama dan upacara-upacaranya. Begitu juga membekali anakanak dengan pengetahuan-pengetahuan agama dan kebudayaan Islam yang sesuai dengan umurnya dalam bidang aqidah, ibadah, mu'amalah dan sejarah. Begitu juga dengan mengajarkan kepadanya cara-cara untuk menunaikan syi'ar-syi'ar dan kewajiban-kewajiban agama, dan menolongnya mengembangkan sikap agama yang betul, dan yang pertama-tama yang harus ditanamkan adalah iman yang kuat kepada Allah, malaikat-malaikat-Nya, kitab-kitab-Nya, rasulrasul-Nya, hari kiamat, dan selalu mendapat pengawasan dari orang

13 Hasan Langgulung, Manusia dan Pendidikan Suatu Analisa Psikhologi dan Pendidikan. (Jakarta: Pustaka Al-Husna; 1986), hal. 56 
tua dalam segala perbuatan dan perkataannya.

Di antara cara-cara praktis yang patut dipergunakan oleh keluarga untuk menanamkan semangat keagamaan pada diri anakanak adalah sebagai berikut:

a. Memberi tauladan yang baik kepada mereka tentang kekuatan iman kepada Allah dan berpegang kepada ajaran-ajaran agama dalam bentuknya yang sempurna dalam waktu tertentu.

b. Membiasakan mereka menunaikan syi'ar-syi'ar agama semenjak kecil sehingga penunaian itu menjadi kebiasaan yang mendarah daging, mereka melakukannya dengan kemauan sendiridan merasa tentram sebab mereka melakukannya.

c. Menyiapkan suasana agamadan spritual yang sesuai di rumah dimana mereka berada.

d. Membimbing mereka membaca bacaan-bacaan agama yang berguna dan memikirkan ciptaan-ciptaan Allah dan makhlukmakhluknya untuk menjadikan bukti kehalusan sistem ciptaan itu dan atas wujud dan keagungan-Nya.

e. Menggalakkan mereka turut serta dalam aktivitas-aktivitas agama, dan lain-lain lagi, dengan cara-cara lain.

Ketika keluarga menunaikan hal-hal tersebut di atas, sebelumnya menurut kepada petunjuk dari al-Qur'an, as-Sunnah Nabi saw., dan peninggalan Assalaf-Assaleh yang semuanya mengajak untuk melaksanakan pendidikan, mengharuskan orang tua mendidikan anak-anaknya akan imandan akidah yang betuldan membiasakannya mengerjakan syari'at, terutama Shalat. Seperti firman Allah swt., "Perintahlah keluargamu bersembahyang dan tekunlah engkau mengerjakannya. Kami tidak minta darimu rezki . kami memberimu rezki. Akibat yang baik bagi yang bertaqwa." Sabda Rasul saw., "Perintahkanlah anak-anakmu untuk bersembahyang sedang mereka berumur tujuh tahun, pukullah mereka kalau tidak mau jika mereka berumur sepuluh tahun, dan pisahkanlah mereka dalam pembaringan." (HR. Abu Daud, Turmudzi, Ahmad dan al-Hakim)

Agama juga mewajibkan mereka menanamkan nilai-nilai agama dan kebiasaan-kebiasaan Islam pada jiwa anak-anakdan menyuruh mereka menghafal sebagian al-Qur'an, Sunnah Nabi saw., dan sejarah sahabat-sahabat dan khulafaurrasyidin supaya mereka terbimbing ke jalan yang lurus. Rasul saw. bersabda, "Hak anak kepada ibu 
bapaknya adalah bahwa ibu bapaknya mengajarkannya kitab Allah swt., memanah, berenang, dan memberinya warisan yang baik." Juga sabda Rasul saw., "Mencintai keluarga Nabi saw. dan membaca Al-Qur'an.”

Selain pendidikan agama seperti yang dijelaskan di atas, pendidikan akhlak dalam keluarga juga sangat besar pengaruhnya terhadap kepribadian anak. Tidaklah berlebihan kalau kita katakan bahwa pendidikan akhlakdalam pengertian Islam adalah bagian yang tidak dapat dipisahkan dari pendidikan agama. Sebab yang baik adalah yang dianggap baik oleh agama dan yang buruk adalah yang dianggap buruk oleh agama. Sehingga nilai-nilai akhlak, keuatamaan-keutamaan akhlak dalam masyarakat Islam adalah akhlak dan keutamaan yang di ajarkan oleh ulama. Sehingga orang muslim tidak sempurnaagamanya sehingga akhlaknya menjadi baik. Hampirhampir sepakat para filosof Islam, bahwa pendidikan akhlak adalah jiwa pendidikan Islam. Sebab tujuan tertinggi pendidikan Islam adalah mendidik jiwa dan akhlak.

Keluarga memegang peranan penting sekali dalam pendidikan akhlak untuk anak-anak sebagai institusi yang mula-mula sekali yang berinteraksi dengannya. Karena mereka mendapat pengaruh daripadanya atas segala tingkahlakunya. Oleh sebab itu haruslah keluarga mengambilberat tentang pendidikan ini, mengajar mereka akhlak yang mulia yang diajarkan Islamseperti kebenaran, kejujuran, keikhlasan, kesabaran, kasih sayang, cinta kebaikan, pemurah, berani, dan lain-lain sebagainya. Dia juga mengajarkan nilai dan faedahnya berpegang teguh pada akhlak di dalam hidup, membiasakan mereka berpegang kepada akhlak semenjak kecil. Sebab manusia itu sesuai dengan sifat asasinya menerima nasihat jika datangnya melalui rasa cinta dan kasih sayang, sedang ia menolaknya jika disertai dengan kekerasan dan biadab. Tepat sekali firman Allah swt., "Jika engkau (Hai Muhammad saw.) kasar dan bengis tentu mereka akan meninggalkanmu." (QS.3: 159)

Diantara kewajibankeluarga dalam penanaman akhlak kepada anak-anak agar memiliki kepribadian yang baik adalah sebagai berikut:

a. Memberi contoh yang baik bagi anak-anaknya dalam berpegang teguh kepadaakhlak mulia. Sebab orang tua yang tidak berha- 
sil menguasai dirinya tentulah tidak sanggup meyakinkan anakanaknya untuk memegang akhlakyang diajarkannya. Di antara kata-kata mutiarayang terkenal dari Ali ra. adalah "medan perang pertama adalah dirimu sendiri, jika kamu telah mengalahkannya, tentu kamu akan mengalahkan yang lain. Jika kalah disitu, niscaya ditempat lain kamu akan lebih kalah. Jadi berjuanglah disitu lebih dahulu”. tepat sekali Firman Allah SWT:"adakah kamu memerintahkan orang berbuat baik sedangkan kamu sendiri melupakan dirimu." (QS:2: 44)

b. Meluangkan bagi anak-anaknya pelung-peluang dan suasana praktis dimana mereka dapat mempraktekkan akhlak yang diterima dari orang tuanya.

c. Memberi tanggung jawab yang sesuaikepada anak-anaknya supaya mereka bebas memilih dalam tindak tanduknya.

d. Menunjukkan bahwa keluarga selalu mengawasi mereka dengan sadar dan bijaksana.

e. Menjaga mereka dari kawan-kawan yang menyeleweng dan tempat-tempat kerusakan, dan lain-lain lagi cara dimana keluarga dapat mendidik anak-anaknya. ${ }^{14}$

Di antara dalil-dalil yang digunakan pendidik-pendidik Islam tentang pentingnya pendidikan akhlak dan pentingnya peranan keluarga di situ, adalah Hadis yang diriwayatkan oleh Al-Bukhari dalam sejarahnya Nabi saw. bersabda, "Tidak memberi seorang bapak yang lebih baik melainkan akhlak yang baik."

Juga diriwayatkan dari al-Turmudzi dan al-Tabrani dari Jabir bin Samrah katanya Rasul saw. bersabda, "Jika seseorang mengajarkan anaknya lebih baik baginya daripada ia bersedekah setiap hari setengah gantang kepada orang miskin.” Diriwayatkan dari al-Baihaqi dari Ibnu Abbas, mereka berkata, "Wahai Rasulullah, engkau telah mengajar kami tentang hak orang tua terhadap anaknya. Maka apa pula hak anak terhadap orang tuanya?" Beliau bersabda, "Bahwa engkau memberi nama yang baik dan membaiki adabnya." Juga diriwayatkan bahwa Beliau saw. bersabda, "Muliakanlah anak-anakmu baikkanlah adab mereka!” (HR Ibnu Majah).

14 Abdullah Nasih Ulwan, Op. Cit., hal. 67 
$108 \frac{\text { Jurnal AL-AFKAR }}{\text { Vol. II, No. II, Oktober } 2013}$

\section{Kesimpulan}

Dari apa yang telah dipaparkan di atas, maka dapat ditarik beberapa kesimpulan sebagai berikut:

Lingkungan keluarga sangat besar peranannya dalam pembentukan kepribadian bagi anak-anak, karena dilingkungan keluargalah anak-anak pertama kali menerima pendidikan yang dapat mempengaruhi perkembangan anak selanjutnya.

Ada beberapa faktor yang menyebabkan buruknya kepribadian anak-anak yang dapat menimbulkan kemerosotan moral pada anakanak, diantaranya: (1) kurang tertanamnya nilai-nilai keimanan pada anak, (2) lingkungan masyarakat yang kurang baik, (3) pendidikan moral tidak berjalan semestinya, baik di keluarga, sekolah, dan masyarakat, (4) suasana rumah tangga yang kurang baik, (5) banyak diperkenalkan obat-obat terlarang dan alat-alat anti hamil, (6) banyak tulisan-tulisan, siaran-siaran, gambar-gambar yang tidak sejalan dengan nilai-nilai moral, (7) kurang adanya bimbingan dalam mengisi waktu luang dengan cara yang baik yang membawa kepada pembinaan moral, (8) kurangnya markas-markas bimbingan dan penyuluhan bagi anak-anak.

Agar anak-anak memiliki kepribadian yang baik dan terhindar dari pelanggaran-pelanggaran moral, maka perlu adanya pembinaan agama sejak dini kepada anak-anak dalamkeluargadan adanya kerjasama antara keluarga, sekolah, dan masyarakat. Sebaik apapun pendidikan moral dalam keluarga tanpa adanya dukungan dari sekolah dan masyarakat, sulit bagi anak-anak untuk memiliki kepribadian yang baik. Begitu juga pendidikan kepribadian di sekolah, tanpa adanya dukungan dari keluarga dan masyrakat, sulit bagi anak untuk memiliki kepribadian yang baik. Dengan demikian ketiga jenis lembaga ini tidak dapat dipisahkan dan harus saling mendukung.

Proses pembinaan nilai-nilai agama dalam membentuk kepribadian anak-anak dapat dimulai sejak anak lahir sampai dewasa. Ketika lahir diperkenalkan dengan kata-kata thayyibah, kemudian setelah mereka tumbuh dan berkembang menjadi anak-anak, maka yang pertama kali harus ditanamkan adalah nilai-nilai agama yang berkaitan dengan keimanan. Sehingga anak meyakini adanya Allah dan dapat mengenal Allah dengan seyakin-yakinnya (ma'rifatullah).

Bersama dengan itu, anak-anak juga dibimbing mengenai nilai- 
nilai moral, seperti cara bertutur kata yang baik, berpakaian yang baik, bergaul dengan baik, dan lain-lainnya. Kepada anak-anak juga ditamankan sifat-sifatyang baik, seperti sifat jujur, adil, hidup sederhana, sabar, dan lain-lainya. Selain itu, agar anak-anak memiliki moral yang baik didalam keluarga, khususnya antara ibu dan bapak juga harus menjaga harmonisasi hubungan antara keduanya dan harus menjadi suri tauladan bagi anak-anaknya.

\section{Daftar Pustaka}

Cakrawala Pendidikan Umum, Bandung: Ikatan Mahasiswa dan Alumni Pendidikan Umum (IMA-PU) PPS IKIP Bandung; 1999

..m.m.m.m.m. Filsafat dan Teosofat Akhlak, Bandung: Rizqi Press; 2011

Abdullah Nasih Ulwan, Pendidikan Anak dalam Islam, Jakarta: pustaka Imani; 2007

Djahiri. A. K, Menelusuri Dunia Efektif, pendidikan Nilai dan Moral, Bandung: Lab. PMP IKIP; 1966

Hasan Langgulung, Manusia dan Pendidikan Suatu Analisa Psikhologi dan Pendidikan. Jakarta: Pustaka Al-Husna; 1986

Ihat Hatimah dkk, Pembelajaran Berwawasan Masyarakat, Jakarta: Universitas terbuka; 2007

Linda N.Eyre Richard, Teaching Your Children Values. New York: Simon Sand Chuster; 1995

M.I. Seolaeman, Pendidikan dalam Keluarga. Diktat Kuliah; 1978

Rohmat Mulyana, Mengartikulasikan Pendidikan Nilai, Bandung: Alfabeta; 2004

Syamsu yusuf, Meretas Pendidikan Nilai, Bandung: Arfino Raya; 2007

Zakiah Dradjat, Membina Nilai-nilai Moral di Indonesia, Jakarta: Bulan Bintang; 1988 


\title{
Eksistensi \\ Pendidikan Anak Usia Dini (PAUD) Terpadu
}

\author{
Asmariani \\ Dosen Manajemen Pendidikan Agama Islam \\ Fakultas Ilmu Agama Islam \\ Universitas Islam Indragiri (FIAI - UNISI) Tembilahan
}

\begin{abstract}
Abstraks
PAUD adalah upaya pembinaan yang ditujukan kepada anak sejak lahir sampai dengan usia enam tahun yang dilakukan melalui pemberian rangsangan pendidikan untuk membantu pertumbuhan dan perkembanagan jasmani dan rohani agar anak memiliki kesiapan dalam memasuki pendidikan lebih lanjut. PembinaanPAUD perlu dilaksanakan secara terpadu dan terkoordinasi, agar kemampuan anak dapat berkembang sesuai dengan usianya.Program PAUD Terpaduadalah program layanan pendidikan bagi anak usia dini yang menyelenggarakan lebih dari satu program PAUD (TK, KB, TPA, SPS) dalam pembinaan, penyelenggaraan dan pengelolaannya dilakukan secara terpadu atau terkoordinasi. Eksistensi PAUD terpadu merupakan sebuah jawaban permasalahan Pendidikan pada suatu komunitas di daerah maka dibutuhkan kerja ekstra dalam membangun agar keberlangsungan dan eksistensi Paud tersebut dapat tercapai sehingga layanan anak dapat terpenuhi. Dalam penyelenggaraan PAUD Terpadu tidak terlepas peran dari pada Masyarakat dan steakholder yang ada didaerah setempat.Peran serta masyarakat diwujudkan dalam bentuk kerja samadan dukungan antara lembaga PAUD, masyarakat dan pemerintah sehingga dapat memenuhi kebutuhan anak di usia PAUD secara optimal sehingga menjadikan generasi mendatang memiliki karekter yang mumpuni.

Kata kunci: PAUD (Pendidikan Anak Usia Dini), Terpadu
\end{abstract}

\section{A. Pendahuluan}

Dewasa ini perkembangan dunia pendidikan kita melalui program sentralistik dan desentralisasi mengalami perkembangan sangat pesat artinya kepedulian pemerintah begitu besar terhadap pendidikan, tidak terlepas dari sektor pendidikan anak usia dini. Oleh karenanya Undang-undang Nomor 20 Tahun 2003 tentang Sistem Pendidikan Nasional Pasal 1 angka 14 menyatakan bahwa Pendidi- 
kan Anak Usia Dini (PAUD) sebagai payung hukum adalah suatu upaya pembinaan yang ditujukan kepada anak sejak lahir sampai dengan usia enam tahun yang dilakukan melalui pemberian rangsangan pendidikan untuk membantu pertumbuhan dan perkembangan jasmani dan rohani agar anak memiliki kesiapan dalam memasuki pendidikan lebih lanjut. Dalam perkembangannya, masyarakat telah menunjukkan kepedulian terhadap masalah pendidikan, pengasuhan, dan perlindungan anak usia dini untuk usia 0 sampai dengan 6 tahun dengan berbagai jenis layanan sesuai dengan kondisi dan kemampuan yang ada, baik dalam jalur pendidikan formal maupun non formal. (UU SISDIKNAS No:20 Th 2003)

Upaya mewujudkan cita-cita tersebut di atas, diperlukan adanya peran serta semua pihak dalam peningkatan dan pengembangan layanan Pendidikan Anak Usia Dini. Pada tahun 2009 menunjukkan bahwa anak yang terlayani program Taman Kanak-Kanak (TK), Raudhatul Athfal (RA), Kelompok Bermain (KB), Taman Penitipan Anak (TPA) dan Satuan PAUD Sejenis baru mencapai 53.19\%. Hal ini berarti masih terdapat $46.81 \%$ anak belum terlayani program Pendidikan Anak Usia Dini. Berbagai strategi telah dilakukan untuk meningkatkan dukungan para pemangku kepentingan yaitu dengan membangun kerja sama dengan Organisasi Kelembagaan, Organisasi Profesi, Organisasi Keagamaan, Organisasi Wanita dan pihak lain yang memiliki komitmen terhadap pendidikan. (Sudibyo: 2012: 1)

Oleh sebab itu pembinaan Pendidikan Anak Usia Dini perlu dilaksanakan secara terpadu dan terkoordinasi, agar kemampuan anak dapat berkembang sesuai dengan usianya. Peraturan Menteri Pendidikan Nasional Nomor 36 Tahun 2010 tentang Organisasi dan Tata Kerja Kementerian Pendidikan Nasional menetapkan bahwa pembinaan pendidikan anak usia dini, baik yang mencakup PAUD Formal (TK/RA), PAUD Nonformal ( TPA, KB dan SPS), dan PAUD Informal, pembinaannya menjadi kewenangan Direktorat Jenderal Pendidikan Anak Usia Dini, Nonformal dan Informal, yang secara teknis dilakukan Direktorat Pembinaan Pendidikan Anak Usia Dini. Artinya tidak ada perbedaan lagi antara anak yang bersekolah di PAUD Formal (TK/RA) dengan PAUD non Formal dan PAUD Informal, sama-sama satu Dirjen yaitu Direktorat Pembinaan Pendidikan Anak Usia Dini. 


\section{$112 \frac{\text { Jurnal AL-AFKAR }}{\text { Vol. II, No. II, Oktober } 2013}$}

\section{B. Hakikat PAUD}

Paedagogos (pendidik atau ahli ahli didik) adalah seseorang yang tugasnya membimbing anak dalam pertumbuhannya agar dapat berdiri sendiri, sedangkan istiah Pendidikan berasal dari kata paedagogiek yang artinya ilmu pendidikan Pendidikan adalah usaha sadar yang dilakukan secara berkelanjutan. (Purwanto, 1995:3)

PAUD Menurut UU No. 20 Tahun 2003 tentang Sistem Pendidikan Nasional Bab 1, Pasal 1, Butir 14, yang menyatakan bahwa : "Pendidikan Anak Usia Dini adalah upaya pembinaan yang ditujukan kepada anak sejak lahir sampai dengan usia enam tahun yang dilakukan melalui pemberian rangsangan pendidikan untuk membantu pertumbuhan dan perkembanagan jasmani dan rohani agar anak memiliki kesiapan dalam memasuki pendidikan lebih lanjut". berikut ini ada pemahaman tentang Pendidikan Anak usia dini yakni:

1. Pendidikan anak usia dini (PAUD) adalah suatu upaya pembinaan yang ditujukan kepada anak sejak lahir sampai dengan usia enam tahun yang dilakukan melalui pemberian rangsangan pendidikan untuk membantu pertumbuhan dan perkembangan jasmani dan rohani agar anak memiliki kesiapan dalam memasuki pendidikan lebih lanjut.

2. Taman Kanak - Kanak (TK) adalah salah satu bentuk pendidikan anak usia dini jalur pendidikan formal yang memberikan layanan pendidikan bagi anak usia 4 - 6 tahun, untuk membantu pertumbuhan dan perkembangan anak, agar kelak siap memasuki pendidikan lebih lanjut.

3. Raudatul Athfal (RA) dan Bustanul Athfal (BA) adalah salah satu bentuk PAUD pada jalur Pendidikan Formal yang menyelenggarakan program pendidikan umum dan program keagamaan Islam bagi anak usia 4-6 tahun untuk membantu pertumbuhan dan perkembangan anak, agar kelak siap memasuki pendidikan lebih lanjut.

4. Kelompok Bermain (KB) adalah salah satu bentuk pendidikan anak usia dini jalur pendidikan nonformal yang memberikan layanan pendidikan bagi anak usia 2 - 4 tahun, untuk membantu pertumbuhan dan perkembangan anak, agar kelak siap memasuki pendidikan lebih lanjut. 
5. Taman Penitipan Anak (TPA) adalah layanan pendidikan yang dilaksanakan pemerintah dan masyarakat bagi anak usia lahir sampai dengan enam tahun sebagai pengganti keluarga untuk jangka waktu tertentu bagi anak yang orang tuanya bekerja.

6. Satuan PAUD Sejenis (SPS) adalah salah satu bentuk PAUD pada jalur pendidikan nonformal (PAUD Nonformal) yang dapat dilaksanakan secara terintegrasi dengan berbagai program layanan anak usia dini yang telah ada di masyarakat (seperti Pos PAUD, Bina Keluarga Balita, Taman Pendidikan Al-Qur'an, Taman Pendidikan Anak Soleh, Bina Iman Anak (BIA), Bina Anak Muslim Berbasis Masjid (BAMBIM), Sekolah Minggu, Pembinaan Anak Kristen (PAK), Pasraman, Vihara dan Sekolah Hindhu). Atau dengan kata lain Satuan PAUD Sejenis adalah salah satu bentuk layanan PAUD Nonformal selain dalam bentuk Taman Penitipan Anak dan Kelompok Bermain yang memberikan layanan pendidikan dalam rangka membantu pertumbuhan dan perkembangan anak, agar kelak siap memasuki pendidikan lebih lanjut.

7. Program PAUD Terpadu adalah program layanan pendidikan bagi anak usia dini yang menyelenggarakan lebih dari satu program PAUD (TK, KB, TPA, SPS) yang dalam pembinaan, penyelenggaraan dan pengelolaannya dilakukan secara terpadu atau terkoordinasi. ( UU No. 20 Tahun 2003 tentang Sistem Pendidikan Nasional Bab 1, Pasal 1, Butir 14).

Adapun tujuan pendidikan adalah untuk mengembangkan pengetahuan dan pemahaman orang tua dan guru serta pihak-pihak yang terkait dengan pendidikan dan perkembangan anak usia dini. Secara khusus tujuan yang ingin dicapai adalah: dapat mengidentifikasikan perkembangan fisiologis anak usia dini dan mengaplikasikan hasil identifikasi tersebut dalam pengembangan fisiologis yang bersangkutan, dapat memahami perkembangan kreatifitas anak usia dini dan usaha-usaha yang terkait dengan perkembangannya, dapat memahami kecerdasan jamak dan kaitannya dengan perkembangan anak usia dini, dapat memahami arti bermain bagi perkembangan anak usia dini, dapat memahami pendekatan pembelajaran dan aplikasinya bagi perkembangan anak kanak-kanak. Dalam ilmu psikologi, diketahui bahwa perkembangan anak manusia terdiri dari beberapa fase-fese perkembangan yang dilaluinya. Ada 3 fase dalam 


\section{$114 \frac{\text { Jurnal AL-AFKAR }}{\text { Vol. II, No. II, Oktober } 2013}$}

mendidik anak yang direkomendasikan, yaitu :

Fase ke-1

7 tahun pertama (Usia 0-7 tahun) perlakukan anak seperti raja karena fase ini fase penyerapan informasi yang sangat berguna.

Fase ke-2

7 tahun ke dua (usia 8-14 tahun) perlakukan anak seperti tawanan perang karena Fase ini merupakan penanamanan sikap dan disiplin.

Fase ke-3

7 tahun ke 3 (usia 15-21 tahun) perlakukan anak sebagai teman karena Fase ini anak membutuhkan tempat terbaik untuk menemukan dan membangun jai dirinya. (Fauzi:1999:79)

Sejalan dengan fase-fase di atas diperlukan kesinambungan pendidikan yang dalami anak, baik dalam keluarga maupun di sekolah, khususnya pada fase pertama usia 7 tahun pertama. Pada usia tersebut anak berada usia sekolah tingkatan PAUD yang bertujuan membentuk anak Indonesia yang berkualitas, yaitu anak yang tumbuh dan berkembang sesuai dengan tingkat perkembangannya, sehingga memiliki kesiapan yang optimal di dalam memasuki pendidikan dasar serta mengarungi kehidupan dimasa dewasa, membantu menyiapkan anak mencapai kesiapan belajar (akademik) di sekolah, intervensi dini dengan memberikan rangsanga sehingga dapat menumbuhkan potensi-potensi yang tersembunyi yaitu dimensi perkembangan anak (bahasa, itelektual, emosi, sosial, motorik, konsep diri, bakat dan minat), melakukan deteksi diri terhadap kemungkinan terjadinya gangguan dalam pertumbuhan dan perkembangan potensi-potensi yang dimiliki anak.

\section{Dasar Hukum PAUD Terpadu}

1. Undang-Undang Republik Indonesia Nomor 23 tahun 2002 tentang Perlindungan Anak.

2. Undang-Undang Republik Indonesia Nomor 20 tahun 2003 tentang Sistem Pendidikan Nasional

3. Peraturan Pemerintah Nomor 19 Tahun 2005 tentang Standar Pendidikan Nasional

4. Peraturan Pemerintah Nomor 48 Tahun 2008 tentang Pendanaan pendidikan 
5. Peraturan Pemerintah dan Nomor 17 Tahun 2010 tentang Pengelolaan dan Penyelenggaraan Pendidikan

7. Peraturan Menteri Pendidikan Nasional Nomor 58 Tahun 2009 tentang Standar Pendidikan Anak Usia Dini (PAUD)

8. Peraturan Menteri Pendidikan Nasional Nomor 36 tahun 2010 tentang Organisasi dan Tata Kerja Kementerian Pendidikan Nasional

9. Rencara Strategis (Renstra) Kementerian Pendidikan Nasional Tahun 2010-2014.

\section{Tujuan PAUD Terpadu}

\section{Tujuan Umum}

Memperluas dan meningkatkan akses dan mutu layanan PAUD bagi anak usia dini ( 0 - 6 tahun), melalui berbagai program PAUD (TK, KB, TPA, SPS) yang diselenggarakan secara terpadu dan terkoordinasi.

2. Tujuan Khusus

a. Meningkatkan akses layanan PAUD bagi anak usia 0 - 6 tahun, melalui berbagai layanan PAUD di lembaga PAUD Terpadu.

b. Meningkatkan tata kelola dan kapasitas lembaga PAUD dalam pengembangan, pembinaan dan penyelengaraan berbagai program layanan PAUD secara terpadu dan terkoordinasi.

c. Meningkatkan efisiensi dan efektifitas dalam perencanaan, pelaksanaan dan pengelolaan layanan PAUD (peserta didik, pendidik dan tenaga kependidikan, pembelajaran , sarana dan prasarana, pembiayaan dan pembinaan PAUD).

d. Target dan sasaran

Target/sasaran Program PAUD Terpadu adalah penyelenggara dan organisasi yang telah menyelenggarakan salah satu program layanan PAUD (TK/KB/TPA/SPS), dan selanjutnya ingin mengembangkan program layanan PAUD lainnya, misalnya TK Pembina/TK Swasta didirikan layanan KB,TPA dan Satuan PAUD Sejenis (SPS), demikian juga sebaliknya. (Kementrian Pendidikan dan Kebudayaan, 2012.4) 


\section{E. Prinsip Program PAUD Terpadu}

Penyelenggaraan PAUD Terpadu harus didasarkan pada prinsip-prinsip sebagai berikut :

1. Proses pembelajaran dilaksanakan dalam suasana yang menyenangkan bagi anak.

2. Proses pembelajaran dilaksanakan melalui bermain yang merangsang anak untuk aktif, kreatif, dan eksploratif.

3. Proses pembelajaran berfokus pada anak secara individu sesuai dengan minat, potensi, dan tahapan perkembangan yang dicapai.

4. Proses pembelajaran mendorong terjadinya interaksi di antara Anak dengan anak, anak dengan orang dewasa, dan anak dengan lingkungannya dalam suasana yang alami.

5. Proses pembelajaran membantu anak agar mandiri, berdisiplin, mampu bersosialisasi, dan memiliki keterampilan dasar yang mendukung perkembangan anak berikutnya.

6. Proses pembelajaran dilaksanakan secara bertahap, berulang, konsisten, konkrit dan tuntas sehingga memiliki kebermaknaan bagi anak.

7. Setiap Satuan PAUD wajib berupaya menampung anak-anak berkebutuhan khusus sebatas kapasitas yang dimiliki dengan tetap menjamin hak-hak anak yang bersangkutan untuk bergaul dengan sesama peserta didik secara wajar serta terlindungi dari perlakuan diskriminatif, baik dari peserta didik lain, pendidik, maupun orang dewasa lainnya.

8. Setiap satuan PAUD wajib memberikan layanan gizi dan kesehatan dasar kepada anak dan/atau mengintegrasikan layanan PAUD dengan layanan gizi dan kesehatan dasar yang diselenggarakan pihak lain.

9. Setiap satuan PAUD wajib menyelenggarakan penyuluhan bagi para orang tua dan keluarga tentang gizi dan praktek kesehatan yang baik.

10. Secara bergotong royong penyelenggaran satuan PAUD bersama orang tua dan masyarakat mengupayakan penyediaan makanan bergizi dan kebutuhan suplemen vitamin yang dibutuhkan anak. 


\section{F. Peranan Masyarakat/Publik Terhadap Eksistensi PAUD Terpadu}

Keberadaan PAUD terpadu merupakan sebuah jawaban permasalahan Pendidikan pada suatu komunitas daerah maka dibutuhkan kerja ekstra dalam membangun agar keberlangsungan dan eksistensi Paud tersebut dapat tercapai sehingga layanan anak telah terpenuhi. Selain itu penyelenggaraan PAUD Terpadu tidak terlepas peran dari pada Masyarakat dan steakholder yang ada didaerah setempat.Melalui dukungan masyarakat yang memadai terhadap penyelenggaraan pendidikan yang bermutu. Peran serta masyarakat diwujudkan dalam bentuk kerja sama antara lembaga PAUD, masyarakat dan pemerintah yang dibangun berdasarkan kebutuhan rill.

Pemberdayaan peran serta masyarakat dapat dilakukan antara lain melalui :

1. Identifikasi Potensi Masyarakat

a. Penggalian sumber dana

b. Menjadi narasumber kependidikan

c. Membantu pengadaan fasititas dan sarana prasarana

d. Membantu penyebaran informasi kegiatan PAUD Terpadu

2. Pihak yang berperan dalam lembaga PAUD Terpadu

Agar bentuk peran serta masyarakat dapat terorganisir secara baik dan berjalan efektif serta efisien, maka dilakukan koordinasi dengan pihak-pihak lain di bawah ini:

a. Gugus PAUD Terpadu

b. Komite Sekolah/PAUD

c. Orang tua

d. Organisasi mitra PAUD yaitu (Organisasi Kelembagaan, Organisasi Profesi,Organisasi Wanita, Organisasi Keagamaan, dan Organisasi lain yang memiliki kepedulian dengan PAUD)

e. Dunia Usaha dan Dunia Industri dalam rangka pendukungan dana

f. Akademisi dan Praktisi.

Identifikasi potensial yang ada di masyarakat serta pihak yang berkompeten dalam penyelenggaraan Paud harus adanya jaringan kordinasi yang mana ini berfungsi sebagai tonggak dan kekuatan suatu lembaga Pendidikan agar eksis dan bertahan selamanya ditengah masyarakat, dikarenakan suatu hal yang mustahil bagi sebuah 
$118 \frac{\text { Jurnal AL-AFKAR }}{\text { Vol. II, No. II, Oktober } 2013}$

lembaga PAUD dapat berkiprah ditengah masyarakat tanpa adanya hubungan kerjasama yang erat.

\section{G. Penutup}

Seiring dengan meningkatnya tuntutan dan kebutuhan masyarakat untuk memperoleh layanan pendidikan, termasuk Pendidikan Anak Usia Dini (PAUD), di seluruh pelosok Negeri maka kebijakan untuk pengembangan Program PAUD Terpadu sebagai jawaban, sangatlah strategis dalam rangka meningkatkan angka partisipasi anak usia dini yang memperoleh layanan PAUD. Oleh sebab itu berbagai upaya telah dan sedang dilakukan untuk memperluas akses layanan dan meningkatkan mutu layanan PAUD Terpadu baik yang mencakup pengelolaan pembelajaran, pengelolaan peserta didik dan pendidik serta tenaga kependidikan, pengelolaan pembiayaan, pengelolaan sarana prasarana serta membangun kerja sama kemitraan bersama Masyarakat.

Akhirnya melalui pengembangan Program PAUD Terpadu ini, diharapkan dapat memberikan dan mendorong peningkatan akses dan mutu layanan PAUD di Indonesia, yang pada gilirannya mampu melahirkan sumber daya manusia Inhil yang unggul, sehat, cerdas, ceria dan berakhlak mulia tentunya menjadikan anak dan generasi mendatang memiliki karekter yang mumpuni.

\section{Daftar Pustaka}

Fauzi, Ahmad, Psikologi Umum, Bandung, CV Pustaka setia, 1999 Muhammad, Hamid, Pedoman Pendidikan Anak Usia Dini Terpadu, Dirjen Pendidikan Anak Usia Dini Non Formal dan Informal, Jakarta, 2012

Sudjarwo, Pedoman Teknis Penyelenggaraan Kelompok Bermain, Direktur Pendidikan Anak Usia Dini, Jakarta, 2008

Sudibyo, Bambang, Peraturan Menteri Pendidikan Nasional Nomor 58 Tahun 2009 Standar Pendidikan Anak Usia Dini, Mentri Pendidikan Nasional, 2009

UU No. 20 Tahun 2003 tentang Sistem Pendidikan Nasional Bab 1, Pasal 1, Butir 14). Jakarta 
Purwanto, Ngalim, Ilmu pendidikan Teoritis Dan Praktis, Bandung, Remaja Rosda Karya, 1995

Purwanto, Ngalim, Psikologi Pendidikan, Bandung, Rosda Karya, 2004 